\title{
Migraciones externas en Chile: bases históricas de un fenómeno complejo
}

\section{Lorenzo Agar Corbinos*}

\section{RESUMEN}

Este artículo trata de las migraciones internacionales en Chile, en particular aquellas ocurridas durante los siglos XIX y Xx, y que han sentado las bases históricas de un fenómeno que hoy impacta con fuerza a la sociedad chilena. La revisión de fuentes pretéritas sirve de sustento necesario y esclarecedor de la ideología que ha predominado en estas materias y que permiten dar adecuado contexto al debate que ilustrará la formulación de una nueva política migratoria para Chile. Esta nueva normativa tendrá que descansar en el reconocimiento de que las actuales migraciones -esencialmente sudamericanas, a diferencia de las europeas y asiáticas de los siglos precedentes- están siendo un punto de inflexión para el reconocimiento de una pluralidad cultural comunitaria la cual, sin lugar a dudas, enriquecerá nuestra forma de vida al igual que lo ocurrido con las migraciones de antaño.

Palabras clave: migraciones internacionales, pluralidad cultural, identidad, ideología, modernidad.

\section{External migrations in Chile: historical bases of a complex phenomenon}

\footnotetext{
* Doctor en Sociología. Profesor Agregado de la Escuela de Salud Pública, Universidad de Chile. Santiago (Chile). lorenzoagar@gmail.com

El autor de este artículo agradece al abogado Jaime Esponda Fernández por los valiosos comentarios y aportaciones que ha realizado a este trabajo.

Recibido: 17 de abril de 2015 / Modificado: 24 de mayo de 2015 / Aceptado: 6 de junio de 2015.

Para citar este artículo

Agar Corbinos, L. (2015). Migraciones externas en Chile: bases históricas de un fenómeno complejo. OAsIs, 22, 49-91. DOI: http://dx.doi.org/10.18601/16577558.n22.04
} 
menon that impacts Chilean society today. The review of past sources serves as a necessary and revealing support of the ideology that has prevailed in these issues and allows an adequate context to be given to the debate that will instruct the formulation of a new migratory policy for Chile. This new regulation will have to rest upon the realization that current migrations (essentially South American, as opposed to the European and Asian migrations of past centuries) are being a point of inflection for the recognition of a cultural communal plurality, which will undoubtedly enrich our way of life just as happened in past migrations.

Keywords: International migrations, cultural plurality, identity, ideology, modernity.

\section{A MODO DE INTRODUCCIÓN}

La conquista de América ha sido, sin duda, una de las más fascinantes proezas acaecidas en la historia de la humanidad. Dos civilizaciones que habitaban un mismo mundo, sin conocerse, se encontraron. El reconocimiento significó un enfrentamiento de civilizaciones a sangre y fuego que, asimismo, trajo consigo la admiración de cada parte por las novedades de la evolución humana en la otra. Unos, los conquistadores, se desplazaron con un propósito de dominación imperial, mientras que otros, los pueblos indígenas, vieron tambalear toda su civilización por la irrupción del poder de la ambición y de las armas. Como ha dicho Oscar Wilde, "donde hay dolor hay un suelo sagrado".

En este caso, el suelo sagrado es América, y cada una de las naciones que allí se han construido ha sido el resultado de la conquista y la imposición de una civilización sobre otra. Sin embargo, lo que hoy vemos en todos los países americanos es la mezcla, tensa y armónica a la vez, de la espiritualidad de los pueblos precolombinos -el elemento fuego-; el racionalismo europeo, tanto en la época de la Conquista como en las migraciones de la era industrial -el elemento aire-; la sangre africana que, tras la tristeza de su desplazamiento forzado nos ha llenado de alegría con sus sensaciones exultantes -el elemento tierra- y, por último, la contribución de árabes y asiáticos que han impreso en estos suelos su impronta de emprendimiento cargado de emoción -el elemento agua-.

Es esta mezcla humana de energías anímicas y formas de organización social, la que ha configurado una región cuya naturaleza es la diversidad cultural de esencia mestiza.

Las tensiones y los conflictos interculturales originados por la conquista, la migración forzada desde el continente africano y las sucesivas oleadas migratorias han marcado la senda del desarrollo en nuestra América mestiza. Los movimientos migratorios han extendido un puente entre lo establecido y lo novedoso, entre lo arraigado y nuevas formas de vida. En cierta forma, podemos decir que se han constituido en uno de los fenómenos más desafiantes de nuestros tiempos. Las tensiones raciales, políticas, religiosas, culturales, al fin y al cabo consecuencia de la conquista europea, han dejado huella social cierta en la conformación de las naciones emergentes y las relaciones interétnicas subsecuentes.

Los europeos descubren un nuevo mundo y son seducidos por el dominio de nuevos terri- 
torios. Durante casi cuatro siglos de conquista y mestizaje, ejercen el poder por el fuego de la guerra sobre unas poblaciones nativas con rico acervo cultural e inician, sin saberlo, una de las empresas humanas de mayor impacto histórico que se haya conocido. Mattelart y Mattelart (1965), en su libro sobre la problemática del poblamiento latinoamericano dicen:

...Los espańoles y los portugueses que vinieron a establecerse en América no fueron muy numerosos y, siguiendo a algunas estimaciones, su número no sobrepasó nunca los 140.000, hacia 1570. Al fusionar a la población negra, se produjo un proceso de mestizaje que trajo consigo una gran variedad de tipos étnicos que constituyen hoy en día, todavía, uno de los elementos demográficos originales de América Latina (p. 45).

En cuanto a las cifras de la inmigración durante el periodo colonial, existen estimaciones de la CEPAL (2006) que nos dan una idea bastante clara respecto del impacto de la demografía en la conformación cultural de las sociedades latinoamericanas. Postula que el imperio español se propuso dirigir y controlar el proceso migratorio, buscando asegurar que los emigrantes fueran súbditos españoles que, además, pudieran probar su "pureza de sangre". Según la CEPAL, se calcula que entre 1504 y 1650 llegaron unos 450 mil espańoles al nuevo mundo, y respecto de la especificidad de la inmigración española se sostiene que estuvo constituida prácticamente por hombres solos y que: ...durante el primer siglo de la conquista, las mujeres alcanzaban solamente el 5\% del total de las personas que atravesaron el océano: un siglo más tarde pasaron a representar aproximadamente el 35\% del total. En consecuencia, el número de mestizos se incrementó regularmente a lo largo de todo el periodo colonial (2006, p. 84).

Por cierto, este es el inicio de la vasta heterogeneidad cultural que presenciamos en América Latina. Sin embargo, esta variedad fue simultáneamente acompańada de una gran segregación social que hasta hoy perdura. De modo que diversidad cultural y segregación social podrían ser las características esenciales de la formación de las naciones latinoamericanas, premisa bajo la cual, junto a otros factores sobrevinientes, es posible analizar el presente de cada nación. En términos globales, concordamos con Mattelart y Mattelart (1965) en su esfuerzo de categorización social de las sociedades coloniales latinoamericanas, en cuanto su origen es producto del cruce cultural entre el mundo nativo aborigen y el mundo europeo. Estos autores identifican "los blancos o españoles, entre los cuales se distinguen los españoles europeos de los españoles americanos o criollos; los indios; los mestizos (descendientes de blancos con indios): los negros, quienes podían ser libres o esclavos; los mulatos (descendientes de negros con blancos) y los zambos (descendientes de negros con indios)" (p. 61) ${ }^{1}$ (tabla 2).

Desde luego, en términos generales, la pertenencia a alguno de estos grupos o la

\footnotetext{
1 Texto original en francés. La traducción al español es responsabilidad del autor de este trabajo.
} 
presencia de una $\mathrm{u}$ otra sangre en el posterior mestizaje han definido en importante medida la posición de cada grupo en la escala social y, también, las posibilidades de movilidad social. Asimismo, debemos reconocer que la mayor mezcla que se produjo en algunos países (p. ej. Brasil y Colombia) ha determinado, por ese solo hecho, una mayor apertura a la aceptación de realidades multiculturales diversas, lo cual no quiere decir, en todo caso, que el proceso histórico de diálogo social étnico no haya estado exento de tensiones y discriminaciones.

A la luz de lo que señalan los autores referidos, se puede sostener que existiría un común denominador latinoamericano, una especie de tipo ideal weberiano, el cual consistiría, en síntesis, en que las futuras naciones latinoamericanas, en la etapa de la conquista, atravesaban un momento "primitivo" o "mágico", catalogable como un aspecto particular de la mentalidad mística. Esta mentalidad habría, entonces, generado una cierta uniformidad de premisas, conclusiones y, en consecuencia, cierto tipo de acciones convergentes en toda la región latinoamericana. Echanove (1963) plantea que alguno de los rasgos culturales generales de América Latina serían: a) el verbalismo, b) la mentalidad mágica, c) el divorcio entre la ley y su aplicación y d) la hospitalidad. Huelga decir que estos rasgos, bajo distintas formas, persisten aún en nuestras sociedades.

En esta misma línea, el connotado sociólogo francés Michel Maffesoli piensa que Latinoamérica, en particular Brasil, constituye un laboratorio de la posmodernidad, producto precisamente de su origen mágico-mestizo, que la coloca en una condición de privilegio para transitar por el camino místico, en esta nueva era posmoderna ${ }^{2}$.

Las posibilidades que se abren actualmente con la globalización pueden considerarse desde fenómenos opuestos, es decir, accediendo a ellas a partir de un mundo más diverso y, al mismo asociadas a los procesos de homogeneización cultural. Dentro de este cuadro, una de las críticas más repetidas ha sido la amenaza que la globalización representa tanto para la identidad del Estado nacional como para la conservación de la diversidad cultural. Esta aprensión se fundamenta en la presunción de que las nuevas tecnologías de la información y la comunicación construyen progresivamente un espacio cultural internacional homogéneo único, que convertiría a estas tecnologías en el medio principal de estandarización cultural.

Sostenemos que el verdadero reto para las sociedades actuales surge de la siguiente constatación: los movimientos migratorios y la globalización han incrementado los contactos entre distintas culturas, lo cual se presenta ante nuestros ojos como un fenómeno esencial, puesto que la estabilidad de los sistemas sociales y culturales depende hoy de la capacidad existente, en la esfera política y social, de convivir con las diferencias en forma cohesionada, es decir, asumiendo que se incrementarán los cruces culturales, los mestizajes y las hibridaciones culturales. De esto se desprende, como desafío, el diálogo intercultural basado en el reconocimiento cierto del "Otro/a" como un "Otro/a"

2 Conversaciones del autor con el sociólogo Michel Maffesoli en París, año 2011. 
legítimo, con el cual es posible comunicarse e, incluso, aprender de su cultura y mejorar el conocimiento de la propia, permitiendo un acercamiento mutuo a una nueva cultura que trascienda los compartimentos estancos.

El vertiginoso avance de la globalización -que provoca la interacción de flujos de activos culturales, de capital y de personas-así como la gradual modernización de los Estados-nación en todo el orbe, impone la ineludible tarea de reflexionar sobre los valores y las creencias que sustentan nuestra existencia. Por lo mismo, es relevante mejorar el conocimiento de la conformación de nuestros pueblos, para lo cual una vía ineludible es la investigación de los procesos migratorios históricos.

Chile es una de las naciones latinoamericanas que ha recorrido, históricamente, un proceso particular de mestizaje que se inicia en pretéritos tiempos coloniales y continúa luego con las migraciones internacionales que se producen en la era de la modernidad (siglo XIX y primera parte del siglo $\mathrm{xx}$ ), con el aporte de las distintas comunidades extranjeras y con las nuevas migraciones externas, que denominamos posmodernas (Agar, 2012).

Producto de las migraciones en la modernidad, nuestro país ha recibido innegables aportes, para su desarrollo, de las comunidades extranjeras. Sin embargo, estas contribuciones plurales se han mantenido en la oscuridad producto de la tendencia secular de concebir todo aporte distinto en la idea de la homogeneidad nacional.

Según el PNud (2014), Chile presenta el nivel de desarrollo humano más alto de América Latina y el Caribe. Para este logro, el aporte del factor humano externo ha sido esencial. Por lo mismo, resulta paradójico que, a pesar de las evidencias de los aportes de las comunidades extranjeras al desarrollo y la diversidad cultural de Chile, persista ese discurso de la homogeneidad que tiene sus orígenes en la formación de la República y cuya justificación originaria podría radicar en la necesidad de particularizar los nacientes Estados-nación del nuevo continente, luego de su independencia de la corona española. En otras palabras, Chile es un país con una rica diversidad cultural comunitaria basada en la presencia de pueblos originarios y de una importante historia migratoria que, sin embargo, no reconoce dicha multiculturalidad, pues subsume los aportes diversos en una idea asociada al Estado-nación. Es así como se ha instalado históricamente y en el inconsciente colectivo la idea de que Chile es un país homogéneo culturalmente, lo cual conlleva una marcada inclinación a invisibilizar las diferencias.

Este imaginario de homogeneidad tan enraizado en el pueblo chileno es producto, en parte, del propósito, consciente o inconsciente, de las élites dominantes para mantener la unidad de la nación en torno a valores patrios monoculturales. Paradójicamente, grupos de inmigrantes han pasado a formar parte de esas élites. Tras aquel propósito late la idea de que la diversidad, la diferencia, el desborde de los márgenes culturales arraigados, podría provocar una disolución de la fortaleza unitaria y, como consecuencia, una traba a la estabilidad y el desarrollo nacionales. Sin embargo, uno de los desafíos de la posmodernidad en la era de la globalización es, precisamente, lograr la visibilización de la heterogeneidad cultural, en un ambiente de pluralidad, pues contraria- 
mente a la idea dominante de la modernidad, hoy día la diversidad se concibe como un factor que potencia el desarrollo.

Chile se ha constituido, desde los años noventa, crecientemente en un país de atracción migratoria, fenómeno que seguramente nos acompañará por mucho tiempo, cambiando drásticamente nuestro paisaje sociodemográfico, étnico y cultural ${ }^{3}$. Además, el país se enfrenta a la necesidad de formular una nueva Ley Migratoria, que dé cuenta de la nueva realidad nacional multicultural y de la actual sociedad global, dejando atrás las ataduras a que lo somete la herencia legislativa de la anterior política, que data de 1975, época de dictadura militar, la cual se caracterizó por un claro sesgo geopolítico ${ }^{4}$.

El reconocimiento, la valorización y la visibilización de las energías y los aportes culturales subterráneos en el desarrollo de la nación nos mostrará en qué medida se limitan y obstaculizan las potencialidades de tal desarrollo cuando, como ocurre todavía, se ensombrecen y no son reconocidas apropiadamente las diversas formas culturales que se han expresado en Chile, a lo largo de su historia, tanto colonial como independiente. En suma, es indispensable reconocer que nuestro progreso como sociedad descansa en la diversidad y no en la unicidad; en el respeto y la afirmación de la pluriculturalidad, más que en la afirmación de la homogeneidad y la monoculturalidad.

Maffesoli (2005) plantea la presencia de una suerte de dualidad, en virtud de la cual, mientras el individuo se construye en el colectivo, una nación se construye en contacto con una o más culturas distintas a la que ha predominado como propia. En la era moderna lo distintivo era el objetivo que se debía seguir, valorizándose lo que unificaba, lo monovalente y lo unidimensional. En cambio, la pluralidad es el signo de la globalización posmoderna, que acentúa la diversidad cultural.

Por lo expuesto, en Chile, es de la mayor relevancia conocer más de nuestra historia migratoria, bajo el supuesto de que mientras más sabemos de nosotros mismos, como nación e identidad cultural, enfrentaremos en mejores condiciones los retos que devienen de las nuevas corrientes migratorias que, a todas luces, han llegado para quedarse y transformar la sociedad chilena. Es el momento de elevar a la conciencia pública el inconsciente colectivo de la diversidad cultural comunitaria presente en Chile.

\footnotetext{
3 Según estimaciones oficiales, actualmente hay cerca de medio millón de extranjeros en Chile, que corresponden a un 2,7\% de la población. La tasa de crecimiento anual de la inmigración ha sido, entre 2002 y 2014, de 13,2\%, mientras que la población del país ha crecido a un ritmo de 1,5\%. La procedencia inmigratoria latinoamericana es mayoritaria, con un $85 \%$ (ver Anexo tabla 1). Un tercio de los inmigrantes son ciudadanos peruanos, un $15 \%$ argentinos y un $14 \%$ colombianos. Es este último grupo nacional el de mayor crecimiento demográfico en los últimos años.

4 El autor de este artículo forma parte del Consejo Técnico de Política Nacional Migratoria del Gobierno de Chile, representando al Ministerio de Desarrollo Social. Uno de los principales objetivos de este Consejo es sentar lineamientos multisectoriales de política migratoria para la formulación de una nueva ley.
} 
El objetivo de este artículo es aportar, en el sentido señalado, al mayor conocimiento de los procesos migratorios en nuestra nación y la mentalidad dominante a la que se enfrentaron, desde sus inicios hasta nuestros días, para poder realizar sobre bases más sólidas el análisis social de los tiempos actuales y vislumbrar con mayor sabiduría los tiempos migratorios que se avecinan.

\section{MIGRACIONES INTERNACIONALES EN LATINOAMÉRICA: UNA VISIÓN GENERAL}

Antes de ingresar en la historia migratoria de Chile, nos parece necesario hacer una breve revisión del contexto de la migración internacional en el continente americano y, en particular, el impacto de estas migraciones en la era de la modernidad.

La movilidad internacional de personas es un rasgo estructural histórico de las sociedades en América Latina. Como consecuencia de este gran patrón migratorio, se ha forjado el sello de gran parte de esas sociedades.

Pellegrino (2003) identifica cuatro grandes etapas en el proceso migratorio de América Latina. La primera se inicia con la Conquista y finaliza con la Independencia, fase en la cual el traslado forzado de población africana fue la respuesta a la necesidad de incorporar trabajadores para asegurar la explotación de productos coloniales. En una segunda fase, especialmente desde mediados del siglo XIX hasta la primera posguerra, Sudamérica recibió una parte de la gran corriente migratoria europea, de modo que la escasez de población se compensaba con el crecimiento demográfico del viejo continente. La tercera fase, desde 1930 hasta
1965, se caracterizó por una migración interna campo-ciudad que hizo crecer en forma desmesurada las grandes ciudades, en un proceso de urbanización que no fue acompañado de una paralela industrialización. Finalmente -cuarta fase-, en las últimas décadas del siglo $\mathrm{xx}$, nuestro subcontinente deja de ser receptor de inmigración trasatlántica y se convierte en expulsor de población hacia los países desarrollados, principalmente Estados Unidos, con profundos efectos en la economía, la sociedad y la cultura de la región.

Alrededor de 60 millones de europeos emigraron hacia América Latina entre 1820 y 1930 , periodo dentro del cual el mayor volumen migratorio se experimentó entre 1870 y 1913. Esta etapa secular de grandes migraciones se interrumpió abruptamente entre las dos guerras mundiales, cuando la divergencia y la desintegración de la economía internacional pusieron fin a los movimientos masivos de mano de obra (Sánchez, 2002).

Para Sánchez, las causas de la emigración europea desde mediados del siglo xIx e inicios del xx fueron, principalmente, las transformaciones que produjo la difusión de la industrialización y, en sentido amplio, la modernización económica, junto con unas mejoras extraordinarias en el sistema de transporte marítimo que permitieron a millones de trabajadores trasladarse desde una Europa con abundante factor humano, a países del nuevo mundo (Estados Unidos, Canadá, Argentina, Australia, entre otros) cuya oferta de tierra era promisoria, tanto en cantidad como en calidad, mientras los factores capital y trabajo eran escasos.

Según Hatton y Williamson (1998), la emigración europea y su persistencia en la eta- 
pa masiva (1860-1913) encuentra explicación básica en los diferenciales de ingresos con los países receptores, pero también en variables demográficas, en un grado de urbanización e industrialización de los países de origen que permitía liberar mano de obra, y en el efecto consecuencial "familia y amigos" - redes sociales, en el lenguaje actual- que da continuidad a los flujos migratorios, mediante la transmisión informal de información que facilitaba el viaje y ayudaba a la inserción social y laboral en el país de destino.

Por su parte, Sánchez apunta como factores de atracción, fundamentalmente, la "escasez de mano de obra, y por tanto, una elevada demanda de trabajo, abundancia de recursos naturales y rápido crecimiento económico derivado de su inserción en la economía mundial y de su capacidad de atracción de capitales y mano de obra del exterior" (2002, p. 22).

Según Ferenczi y Willcox (1929), alrededor de 52 millones de personas compusieron el movimiento de emigración intercontinental, entre 1824 y 1924. En líneas gruesas, se puede desprender que, de esos flujos, el $72 \%$ se movilizó hacia Estados Unidos, el $21 \%$ hacia América Latina y el 7\% hacia Australia. De los 11 millones de personas cuyo destino fue América Latina, la mitad se dirigió a Argentina, el $36 \%$ a Brasil, y el resto se distribuyó entre los demás países latinoamericanos (tabla 3). De las nacionalidades que componían esta inmigración, el $38 \%$ eran italianos, el $28 \%$ españoles y el $11 \%$ portugueses. Los italianos predominaron en las corrientes de emigración hacia América Latina hasta alrededor de 1905, cuando los españoles comenzaron a ser el grupo más numeroso. Del total de la emi- gración italiana entre 1881 y 1924, alrededor del $45 \%$ se dirigió a otros países europeos, un $30 \%$ a Estados Unidos, un 13\% a Argentina y el $9 \%$ a Brasil.

Según la cepal (2006), la atracción de inmigración europea figuró entre los primeros objetivos de las repúblicas latinoamericanas, con el fin explícito de generar vínculos con los centros de poder económico en el mundo. Para Pellegrino (2000), dicho objetivo inmigratorio se basó en los supuestos doctrinarios predominantes en Europa, que identificaban el volumen demográfico con el progreso económico y con el poderío militar. Al mismo tiempo, tal propósito revestía carácter geopolítico, pues la población de territorios contribuiría a fijar las fronteras de las nuevas naciones, entonces difusas. Pero quizás la motivación más característica de los proyectos de inmigración desde el norte de Europa en que se concretó aquel objetivo, expresada en el lei motiv de las normativas que los regulaban, era la visión idealista del aporte que se atribuía a esas poblaciones al logro del desarrollo, condensada en la idea de que, junto con sus familias y sus herramientas, transmitirían una idiosincrasia de orden y trabajo necesaria para encauzar el progreso.

Durante las primeras décadas de independencia se instala en la región una primera oleada de extranjeros constituida por aventureros, exiliados políticos, científicos, comerciantes y religiosos. Después de 1860, se produce un gran crecimiento del flujo migratorio hacia los países de América Latina. La crisis económica que aqueja al continente europeo entre 1873 y 1896 obliga a miles de sus habitantes a abandonar sus hogares con la esperanza de lograr una mejor calidad de vida. A esta inmigración, 
calificada por Girault (1979) como "aquella de la miseria pura”, se añade la constituida por agricultores calificados, técnicos, negociantes, ingenieros, etc., que responden a las posibilidades de cierto enriquecimiento que ofrecen los nuevos países. Parte de este movimiento se dirige hacia los países del Cono Sur, a la vez que los gobiernos multiplican sus iniciativas para mejorar la acogida de los inmigrantes, mientras las grandes compañías navieras aseguran los desplazamientos masivos.

Las migraciones europeas hacia el continente americano se sitúan en un contexto de rápido crecimiento de la población mundial, en particular la europea, debido a la continua y elevada tasa de natalidad y al descenso en la tasa de mortalidad, como consecuencia del progreso de la medicina y el control de las enfermedades. Así, en el periodo 1800-1900, la población mundial pasa de cerca de 900 millones a alrededor de 1.600 millones, y la esperanza de vida, de cerca de 35 años a 50 años. Este gran crecimiento demográfico ejerció fuerte presión sobre el mercado laboral, debido al incremento de la población en edad activa, pero no pudo ser absorbido por el sistema económico de la época. $\mathrm{Al}$ mismo tiempo, la necesidad de materias primas extraíbles en diversas regiones del mundo motivó desplazamientos y asentamientos de población en esas nuevas zonas de explotación y de inversión. Una de esas zonas era América, cuyos países requerían aquella explotación y, por tanto, esa mano de obra para su propio desarrollo, de modo que de la explotación de sus recursos dependía el éxito o fracaso de sus economías. Las condiciones estaban, pues, dadas para la recepción de los emigrantes potenciales, a quienes solo cabía adoptar la decisión final de marcharse.

A pesar de que las condiciones favorecían el movimiento migratorio, la salida de la tierra natal y la posterior integración en los países de destino no fue fácil. Se promovía esencialmente una inmigración desde Europa del Norte, buscando asociar el nuevo contingente poblacional a la creación de una clase capitalista antifeudal de la que carecían estos países, vista como necesaria para lograr el progreso y la modernización de América Latina, y se declaraba la oposición a la inmigración de razas consideradas "inferiores" (por ejemplo, asiáticos, árabes y africanos) $)^{5}$.

\section{UNA MIRADA AL PROCESO SOCIAL HISTÓRICO DE LAS MIGRACIONES EXTERNAS EN CHILE}

Repasaremos, a continuación, el proceso migratorio en Chile, desde los albores de su vida independiente hasta nuestros días.

Nos interesa, particularmente, determinar algunos elementos del contexto migratorio

5 Por ejemplo, la desconfianza y reparo respecto de la inmigración china, se manifestaba en 1915 en la Cámara de Diputados de Chile. El diputado Rafael del Canto, luego de expresar la persistencia y el aumento del problema, señalaba que "por desgracia nada práctico se ha hecho hasta hoy. Entre tanto, la invasión de inmigrantes de raza amarilla aumenta de una manera alarmante en las provincias del norte. Los vapores que se han dedicado al comercio regular entre nuestros puertos y los del Extremo Oriente, han traído en los últimos siete años, millares de coolies” (Jara, 2002, $\mathrm{s} / \mathrm{n})$. 
durante la era colonial, para luego observar las migraciones que se producen en el Chile independiente y su desarrollo bajo las reglas de la naciente modernidad europea que, por cierto, impregna toda la sociedad latinoamericana $y$, en especial, la chilena.

Desde la independencia de Chile, un número significativo de inmigrantes ejerció roles sobresalientes en diversas actividades e influyeron directamente en el desarrollo político, económico, social y cultural de nuestro país. No es posible desconocer dicha contribución a la formación del Estado, y a la producción y el enriquecimiento de la educación y la cultura. Tampoco es necesario indagar en exceso para encontrar nombres de distintos foráneos que ejerciendo roles de relevancia en los distintos sectores productivos de nuestra economía, fueron determinantes para el desarrollo de las actividades industriales de los siglos $\mathrm{XIX} \mathrm{y} \mathrm{xx}^{6}$. Lo anterior se consolida con el paso de los años, de modo que los extranjeros se posicionaron rápidamente en un sitial de privilegio en el escenario local, pasando a formar parte de la élite y llegando a desempeñar un rol fundamental en los distintos ámbitos del desarrollo de nuestro país (Agar, 2014; García, 2009).

\section{LAS MIGRACIONES EN CHILE: NOTAS SOBRE LA ÉPOCA COLONIAL}

Durante los siglos XVI y XVII, los extranjeros que llegaron a nuestro territorio, bajo dominio español, fueron principalmente españoles castellanos y extremeños. Desde un comienzo, junto con los conquistadores, arribó al país un número indeterminado de esclavos de origen africano, los cuales constituyeron un pequeño porcentaje de la población chilena. Posteriormente, sus descendientes, llamados "pardos" por los espańoles, fueron asimilados a través del mestizaje, pero la mayoría abandonó el país rumbo al Perú, con el Ejército Libertador, de modo que quedó escaso vestigio cultural de su presencia. En el siglo XviII, llegaron espańoles de origen vasco y, luego, la lucha por la independencia atraería soldados y comerciantes europeos que la apoyaban, especialmente ingleses, italianos, irlandeses y franceses, quienes se establecieron en el país.

A partir de la Independencia, la inmigración en Chile fue un fenómeno social de magnitud demográfica reducida, pero de elevado valor cultural, social y económico. Como en los demás países del continente, durante los siglos XIX y xx se produce una importante inmigración colonizadora de origen europeo, patrocinada por el Gobierno, constituida principalmente por alemanes, británicos, italianos, holandeses, croatas, suizos y franceses.

Villalobos, Silva, Silva y Estellé (1976) ilustran este fenómeno de la siguiente manera:

...La colonización de la Araucanía se hizo en buena parte con nacionales (aunque) no se dejó de lado la idea de colonizar con extranjeros. En 1872, se dio, con tal propósito, el carácter de Oficina General de Inmigración a la Sociedad Nacional de Agricultura,

\footnotetext{
6 Según el Censo Industrial y Comercial de 1937, realizado por la Dirección General de Estadística, el 24\% de las industrias de Chile eran de propiedad de extranjeros.
} 
y dos años más tarde, se creó el cargo de Inspector de Colonización para el territorio de indígenas. Sin embargo, el arribo de inmigrantes se activó solo a raíz de la designación de un agente general de colonización en Europa. Los primeros inmigrantes llegaron en 1883 y, hasta 1890, año en que suspendió el envío de colonos contratados, su número ascendía a poco más de 10.000 personas de ambos sexos, en especial suizos, españoles, franceses, ingleses y alemanes (p. 600).

Desde principios del siglo xx y hasta el inicio de la Segunda Guerra Mundial, llegan de manera espontánea numerosos inmigrantes desde territorios dominados por el Imperio otomano, que hoy corresponden a Siria, Líbano y Palestina. Los provenientes de este último territorio constituyen hoy la colectividad más numerosa de palestinos fuera de Medio Oriente. También, finalizada la Guerra Civil española arriban, desde campamentos de refugiados en Francia, españoles republicanos ${ }^{7}$.

Es reconocido que todos los inmigrantes referidos precedentemente hicieron un importante aporte social, cultural y económico a Chile. Las comunidades se distribuyeron a lo largo del territorio logrando influencia allí donde se asentaron: los de origen germano en la zona sur, especialmente en las regiones de la Araucanía, Los Ríos y Los Lagos; los croatas en las ciudades de Antofagasta (norte de Chile) y Punta Arenas (extremo sur); los británicos en Santiago, Punta Arenas, Valparaíso y otras ciudades costeras debido a su estrecha relación con la Armada. Por su parte, los árabes se distribuyeron a lo largo del país, especialmente en provincias, producto de la migración en cadena y su particular actividad económica itinerante (Agar, 2009).

Varios historiadores coinciden en que, a la llegada de los conquistadores españoles, la población del territorio chileno oscilaba entre medio millón y un millón y medio de habitantes, pero la guerra de Arauco - que disminuyó la natalidad y aumentó la mortalidad-, las enfermedades infecciosas y recurrentes desastres naturales, como el terremoto de 1575 , contribuyeron a desarreglar la derivación normal de las cifras de población mencionadas, de modo que la población, en vez de crecer, disminuyó. Es debido a este fenómeno que, desde el sector productivo, se comienza a demandar población de reemplazo desde África, que llega como mano de obra. Si bien este no fue un grupo humano de gran magnitud, contribuyó a la formación de la diversidad étnica, aunque en un rango proporcional inferior al de las mezclas que se fueron conformando entre los colonizadores europeos e indígenas, fenómeno que, por su parte, contribuyó a que la población netamente espańola en territorio chileno permaneciese casi estacionaria ${ }^{8}$.

Es conocida la historia del vapor Winnipeg, que trajo por obra de Pablo Neruda, en ese entonces cónsul de Chile en París, 3 mil refugiados españoles, entre ellos la madre y los abuelos del autor de este artículo.

8 Una reciente investigación científica sobre la genética de la población de Chile ha mostrado que un chileno promedio tendría un 44,3\% de aporte genético de pueblos amerindios; un 51,9\% de europeos y un 3,8\% de africanos (Fuentes, 2014). 
Según lo observado por Fuenzalida (1906) en su libro sobre la evolución social de Chile entre 1541 y 1816 -documento de alto valor si se considera la escasa información de la época sobre las migraciones- señala que durante los primeros ańos de la conquista hubo libre internación de italianos, griegos y gentes de distintas procedencias. Nos hace ver que Espańa necesitaba del esfuerzo de todos para descubrir, navegar y colonizar. Apunta que los extranjeros llegaban a Chile sin trabas y mezclaban su sangre en una proporción considerable. Aparentemente, esta tolerante aceptación de los inmigrantes se generaba en Chile y no desde la Corona española. Fuenzalida conjetura que debido a lo escaso de la población de Chile durante la época colonial fue abundante el aporte de sangre extranjera. Dice:

...desde los días de la conquista, i en este período -unos 50 o unos 60 años aproximadamente- fué libre la entrada i estadía de estranjeros, puede inferirse lógicamente que el mestizaje chileno está lejos de reunir esa pureza étnica que han dado en la flor de atribuirle algunos escritores [Existía] sin lugar a duda la disconformidad entre la realidad [y lo que] disponían las leyes en materia de estranjería, pues mientras estas contienen preceptos tan terminantes en el sentido del aislamiento de la población indiana, los hechos descubren una tolerancia efectiva, no tan solo en la época de la primera formación del pueblo chileno, sino en aquella en que la vijilancia del rei i de su Casa de Contratación parecían ser rigurosas e implacables (pp. 78-79).
Resulta muy interesante descubrir en estas líneas, por un lado, el reconocimiento de una diversidad étnica en nuestros orígenes, y por otro, el divorcio entre las leyes y la práctica, rasgo ya mencionado y vigente aún, según nuestra mirada; y también el imaginario de la época sobre la pretendida pureza étnica del chileno, a que alude Fuenzalida.

En suma, hacia fines del siglo XvI, el territorio de Chile ocupado por los españoles (entre la zona de Copiapó, por el Norte, y el Biobío por el Sur) contenía unos 150 mil habitantes, de los cuales un $72 \%$ eran españoles y mestizos, un $13 \%$ indígenas y mestizos cargados de sangre aborigen, un $10 \%$ negros, mulatos y zambos ${ }^{9}$, y un $5 \%$ indios pacíficos en la isla de Chiloé.

Sobre la población de españoles llegados a Chile entre 1540 y 1630, Encina estima que alcanzaban los $12 \mathrm{mil}$. De ellos, los andaluces y afines del sur de España formaban el 56\%; los castellanos viejos y leoneses, el $24 \%$; y el $20 \%$ restante correspondía a otras procedencias regionales y a los extranjeros (1983, p. 177). Encina, insigne historiador chileno, plantea una interesante hipótesis surgida de la información escrita, que recoge con acuciosidad y, por cierto, con imaginación perspicaz, que destaca la elevada sangre germana presente en los conquistadores españoles que arriban a Chile y que juegan un importante papel en la formación del carácter nacional, planteamiento que encontrará, por cierto, seguidores y detractores. Dice al respecto Encina:

\footnotetext{
9 A fines de la Colonia, este grupo de población estaba muy mermado por el clima, las enfermedades, el rechazo de la población indígena y, desde el siglo XviII, el cese de su internación.
} 
La selección sicológica engendró una selección étnica: el castellano viejo, el andaluz, el leonés, el extremeño, etcétera, que pasaron a Chile, traían en sus venas una alta proporción de sangre germana. Esta sangre, dispersa en la península en un corto número de individuos, que salpicaban la gran masa, se concentró en Chile en los doce mil mestizos ibero-godos que vinieron hasta 1630 , y, en menor proporción, en los que continuaron llegando más tarde, y pesó sobre el temperamento el carácter y el intelecto chilenos (1983, p. 178).

Si se considera que la inmigración internacional en Chile no tuvo las características de un asentamiento masivo demográfico, como ocurrió, por ejemplo, en Argentina, coincidimos con las apreciaciones de los estudios poblacionales de Mattelart y Mattelart (1965), en el sentido que los chilenos serían, en un $80 \%$ de ascendencia indígena. Por su parte, Rosenblat (1945) señala que hacia 1650 la población de Chile era de 550 mil habitantes, de los cuales un $94 \%$ estaba constituido por indígenas, un $3 \%$ por blancos y un $3 \%$ por mestizos, negros y mulatos.

Respecto a la formación de la nueva raza chilena y su originalidad constitutiva, la cual, a diferencia del resto de países latinoamericanos, se reflejaría, entre otros factores, en las escasas diferencias socioterritoriales, Encina sostiene lo siguiente:

El cruzamiento del ibero-godo con la hembra chincha-chilena y mapuche se realizó en buenas condiciones biológicas. A pesar de las grandes diferencias físicas de las razas progenitoras, los caracteres, en vez de divorciarse, se unieron formando un tipo inter- medio más bajo, más braquicéfalo y de cabellos más oscuros que el del conquistador. Bajo la influencia de factores favorables, creados por el régimen colonial, la reversión atávica hacia los caracteres ancestrales se redujo al mínimo, el tipo intermedio se consolidó en una nueva raza histórica en el corto espacio de dos siglos. Quedó en pie la gama que va desde el español rubio del siglo xvi hasta el aborigen también casi puro, pero sin separaciones regionales ni divergencias irreductibles (1983, p. 169).

El imaginario y el propósito homogeneizadores se inician muy temprano en nuestra historia. Las políticas de inmigración restrictivas impulsadas por la Corona y ejercidas por Ambrosio O'Higgins hacia el siglo XVIII así lo muestran. Fuenzalida (1906) señala lo siguiente sobre O’Higgins, padre del Libertador:

...Ese gobernador de Chile i mas tarde virrei del Perú, sufriendo como habia sufrido en cabeza propia i en la de sus amigos los efectos de las leyes sobre estranjería, fue en el mando el mas tremendo de los perseguidores de cuanto elemento demográfico estraño asomó por nuestro suelo.

[...] Para mantenerse grato al soberano i hacer insospechable su conducta funcionaria vijiló, como Argos de cien ojos, nuestras costas para que no se filtraran los enemigos de la fe. Llevó su celo hasta los estremos mas pueriles, para alejar hasta la sombra de una tacha, su celo anti-estranjeril, él que llevaba en sus venas sangre irlandesa, él, que llevaba en su cerebro ideas de progreso, él, que llevaba en su espíritu, organizador i potente, acomodado a las soluciones rápidas, un temperamento tan propio para resolver acertadamente, sin embargo, se dejó voluntariamente 
enredar en las ridículas telarañas de la persecución al estranjero (pp. 185-187) ${ }^{10}$.

La precedente nota se ve corroborada por la circunstancia de que, durante el siglo XviII, diversos grupos poblacionales originarios del continente europeo venían a Chile con el propósito de naturalizarse españoles, para poder permanecer en estas tierras, lo cual, sin embargo, no era tarea fácil, como lo destaca el mismo Fuenzalida en las siguientes líneas:

A trueque de obtener esta concesión los hijos de Italia, como los de otros países, no vacilaban en alistarse bajo las banderas hispanas para combatir las huestes araucanas sublevadas. Estos servicios eventuales prestados con un propósito escusable en aquella época, no fué, sin embargo, recompensado por el rei. [...] Todo lo contrario. Ni siquiera concedió cartas de naturalización a los que comandaron esas huestes extranjeras (1906, p. 63).

A mediados del siglo XVIII, recrudeció el rigor persecutorio en contra de los extranjeros. Recuerda Fuenzalida que por todos los rincones del país se les buscaba y que ellos escondían su verdadera nacionalidad de origen utilizando diversos ardides. Así, nos refiere que:
No hubo ningún francés, oriundo de la rejion pirenaica, que no dijera ser catalán o vasco. No hubo ningún portugués que no jurara ser de la raya de este lado, radicándose originariamente en Estremadura a lo sumo. Nunca faltó un par de testigos para que así lo declararan ante la justicia. Las escusas son de tela tan burda que no es de suponer que a los majistrados no se les alcanzara en qué estribaba el arbitrio discurrido para ir las leyes sobre extranjería (1906, pp. 70-71).

Con todo, queda claro que las autoridades coloniales buscaban subterfugios, clásicos en la sociedad chilena, destinados a permitir que la dinámica social se impusiera, mediante una benigna burla de las leyes restrictivas. Quizá, en esa época deba encontrarse el origen del persistente divorcio, a lo largo de Chile, entre las normas legales y ciertas prácticas administrativas que ceden ante ciertas necesidades, demandas o usos sociales. La explicación de aquellos subterfugios se puede respaldar en lo que señala Fuenzalida cuando dice: "los funcionarios honradamente empeñados en hacer prosperar las nuevas ciudades, comprendían de sobra que los mejores elementos para la identificación, para la traza del término de aquéllas, eran esos estranjeros industriosos, activos, económicos, que entendían de muchas

10 Paradójicamente, su hijo, don Bernardo O’Higgins, el padre de la patria, trabaja en sentido contrario. Vergara dice: "Obtenida en 1817 la victoria en la batalla de Chacabuco, O’Higgins trabajó con gran empeńo por conseguir el fomento de la inmigración extranjera, no tanto por el aumento de la población, como por contar con hombres que por su cultura pudiesen contribuir al desarrollo de la industria nacional. Mas, sea por esta o por otras causas, el hecho es que mediante su política se favoreció la inmigración i con ella el aumento de la población i la fuerza i virilidad del pueblo chileno" (1900, s/n). 
cosas por el hecho de haber visto mucho en otras latitudes" (1906, pp. 70-71).

Para Encina, la población de Chile, hacia 1810, fluctuaba en torno al millón de almas, equivalente aproximadamente al número de aborígenes en 1541. Esta merma la atribuye a la absorción por la raza espańola, a las epidemias contra las cuales carecía de inmunidad natural, y a la guerra intestina. Por su parte, el censo de 1812 atribuye a Chile una población algo superior a las 900 mil almas. Las estimaciones de la población indígena oscilan entre el 10 y el $20 \%$ del total que se menciona (1983, t. 8).

Según Vicente Pérez Rosales ${ }^{11}$ (1857), la población de Chile, sin incluir la indígena, de imposible enumeración, llegaba a mediados del siglo xv a 1,4 millones de almas aproximadamente. Según sus cálculos el 1,4\% estaba integrado por extranjeros y el resto de estos habitantes no indígenas pertenecía a la raza europea nacida en Chile y a los criollos que resultaban del cruzamiento de los indios con los españoles. El mismo autor se atreve a trazar un cuadro demográfico-étnico de la población chilena, con cifras de 1854, que calcula en cerca del millón y medio de habitantes, de los cuales un $98 \%$ eran mestizos o, como él los llama, criollos; un 0,5\% europeos, un $0,8 \%$ sudamericanos y un $0,7 \%$ araucanos. Un $20 \%$ de la población vivía ese año en la capital Santiago ${ }^{12}$.

\section{Las Migraciones internacionales en CHILE: ENTRE LA INDEPENDENCIA Y LAS GUERRAS MUNDIALES}

En las últimas décadas del siglo xIx, Pérez Rosales manifestaba un claro sentimiento de satisfacción por el progreso que mostraba Chile y llamaba a proseguir, sin cesar, la política de poblamiento con nuevos inmigrantes, aunque deparase notables sacrificios al Estado (1870).

Esta política no es ajena al ideario de los gobernantes y pensadores de las naciones del sur continental, desde los primeros años de vida independiente, los cuales coinciden en fomentar la inmigración europea como una forma de incorporar al nuevo continente en el progreso mundial. Basados en la creencia de que las naciones europeas constituyen una civilización superior, la inmigración desde ella, pensaban, impactaría positivamente en estos Estados en formación. Esta es la creencia imperante que atraviesa gran parte de los textos

11 Hombre de Estado, político, diplomático y activo agente de colonización de Valdivia y Llanquihue durante el Gobierno de Manuel Montt desde el año 1850.

12 En Subercaseaux (2007), se cita a Luis Thayer Ojeda, quien en su texto de 1919 "Elementos étnicos que han intervenido en la población de Chile", establece la existencia de proporciones raciales en el país luego de varios siglos de colonización, exterminio de población indígena y proceso de mestizaje, con los siguientes porcentajes: 64,89\% de raza blanca, $34,26 \%$ de raza roja o indígena, $0,98 \%$ de raza negra y $0,17 \%$ de raza amarilla (p. 77 ). 
fundacionales que apoyan la llegada de inmigrantes europeos (González, 2004) ${ }^{13}$.

El 10 de octubre de 1882, mediante decreto supremo, el Gobierno crea la Agencia de Colonización General en Europa, que tiene por misión el reclutamiento de inmigrantes europeos. Francisco de Borja Echeverría es designado como Agente General y se elige París como sede, pues se consideraba que las leyes francesas ofrecían gran libertad para este tipo de operaciones.

Los gobiernos chilenos de fines del siglo XIX y comienzos del siglo Xx consideran que el asentamiento de población no indígena europea en los territorios del sur, conquistados a los nativos, es un instrumento para imponer el poder del Estado y desarrollar el crecimiento económico en estas "nuevas" regiones. Como ya lo hemos aseverado, en el imaginario de las élites chilenas, el elemento europeo es considerado como superior al elemento "nacional". El asentamiento de población europea es considerado "un seguro", como parte del plan de incorporación de los nuevos territorios "al mundo civilizado" y del desarrollo de su potencial económico. Sin embargo, a pesar de la aplicación de una política promotora de la inmigración por los gobiernos de Balmaceda (1886-1891) y Pedro Montt (1906-1910), Chile no es elegido por los emigrantes euro- peos o asiáticos como uno de sus principales destinos, contrariamente a lo que acaece en los países vecinos de América del Sur (Fernández, 2006).

Hasta el comienzo de la Primera Guerra Mundial, las autoridades chilenas contabilizan una entrada media anual de mil inmigrantes europeos (espańoles, italianos, suizos, yugoeslavos, alemanes, franceses, principalmente) que se asentarían en las tierras del sur del país. La causa principal del reducido número de inmigrantes en Chile, en relación con los países vecinos, residía en la ausencia de tierras agrícolas susceptibles de ser distribuidas a los nuevos colonos, a lo cual se añadían las malas condiciones climáticas de las regiones llamadas a ser colonizadas y las dificultades para relacionarse con la población autóctona. En muchos casos, los colonos se decepcionan al constatar la diferencia entre las promesas realizadas por las compañías colonizadoras y la realidad con que se encuentran (Fernández, 2006).

Pese a la irrelevancia cuantitativa de la inmigración europea en Chile, el mismo Fernández afirma la idea de su relevancia cualitativa, cuando dice:

Aunque el aporte cuantitativo de la emigración europea no sea, en principio, importante en el total de la población chilena, una parte de estos emigran-

13 Fernández (2006), en un interesante y bien documentado texto sobre la emigración francesa en Chile, entre 1875 y 1914, refiere que luego de la independencia, Chile recibe inmigrantes europeos, en su mayoría de origen inglés, que se instalan en la capital y en los puertos del país. Se trata, principalmente, de comerciantes y empleados de casas comerciales europeas. Según este autor, los europeos que llegan a Chile antes de 1860 son mayoritariamente comerciantes y profesionales liberales. Entre 1846 y 1875, el país acoge una importante oleada migratoria proveniente de Alemania y, tras 1880, el flujo migratorio aumenta y el origen nacional de inmigrantes, que llegan por contingentes, se diversifica, destacando los de origen proletario y de bajo nivel formal educativo. 
tes se dirige hacia los nuevos territorios del sur donde se constituyen en elementos de una naciente clase media. Estos emigrantes son empresarios agrícolas o industriales, comerciantes, encargados de casas de importación, que amplían el mercado chileno. Son los mejores representantes de los productos de su país, elementos esenciales para desarrollar el comercio de sus países respectivos y los principales compradores potenciales de bienes de consumo y de bienes de producción que provienen de sus países de origen. Otra parte de la emigración europea se instala en las ciudades más importantes de Chile donde crean negocios comerciales que se aprovisionan de productos manufacturados que provienen generalmente de la industria europea (2006).

Además, sin perjuicio de la menguada realidad cuantitativa, se trataba de emigrantes que llegaban para quedarse, lo cual respondía plenamente a un incentivo de la mayor relevancia para venir a esta emergente tierra insular-enclaustrada entre la cordillera, el mar, el desierto y los hielos antárticos-consistente en la posibilidad de que, en ellos, se cumpliese una de las promesas de la modernidad y el capitalismo naciente: convertirse en propietarios y ciudadanos a cabalidad. Al respecto, expone Pérez Rosales:

La seguridad de llegar desde luego a ser propietario, satisfacía en el ánimo del pobre labriego y del gañan europeo un sueño encantador que los acompaña, sin llegar casi nunca a ser realidad, desde la cuna hasta el sepulcro; y la de ser ciudadanos de una república, donde las voces de amo y ciervo no tienen significado; donde la virtud y el trabajo son nobleza; donde hay educación para los hijos y templos para los disidentes religiosos; donde no hay más contribucio- nes que pagar que aquellas que señala una ley en cuya formación tienen parte los mismos contribuyentes, le daba la perfecta convicción que lejos de perder con la mudanza de patria ganaba en ello. El gobierno, pues, al fomentar la ley que dejo citada, supo sobreponerse a la preocupación general, ofreciendo al emigrante junto con el halago de la propiedad como base, todos los otros medios que aislados, se consideraban bastantes para hacerle venir hacia nosotros $(1870, \mathrm{~s} / \mathrm{n})$.

Según Walbaum (2004), uno de los factores de atracción que presentaba Chile para los inmigrantes europeos durante el siglo XIX era la existencia del puerto de Valparaíso, que permitía la distribución de mercadería al resto de los países latinoamericanos y se había constituido en centro de operaciones de las empresas extranjeras. En la segunda mitad del siglo XIX, esta ciudad se convierte en la capital financiera e industrial de Chile, y en la segunda más poblada después de Santiago.

Otro factor que favorecía la inversión extranjera y era atractivo para los inmigrantes, consistía, sin duda, en la marcada estabilidad política exhibida a partir de 1830 , solo levemente alterada por los sucesos de 1851 y que se extendió hasta 1891.

Vicente Pérez Rosales, en su papel de coordinador de la inmigración en el sur de Chile, expone que la colonización es necesaria allí donde se esté en presencia de una nación "que tenga desiertos que poblar, industrias que introducir, amor al trabajo que crear, mendigos a quienes mantener, inválidos a quienes premiar, criminales a quienes reformar”. Y continúa diciendo que "la colonización es lo único que puede alcanzar entre nosotros el grado de perfección humana apetecible, i bien considerada, 
es el primero i más seguro paso que puede darse en obsequio de la inmigración” (1857, p. 87).

Según la visión de González (2004), en el Chile de la época posindependencia se instala de manera absolutamente visible una sola forma de pensar, que admite reformas, adaptaciones, matices, pero que es solo una y produce uniformidad en la producción y el consumo. En efecto, la producción cultural, desde los inicios de la era independiente, está centrada en la valorización de la uniformidad como valor principal, moderno y eurocéntrico, que invade todos los ámbitos de la sociedad.

Norambuena (1995) agrega que la utopía agraria, la civilización y el progreso son los conceptos centrales de los procesos de colonización organizados por los gobiernos y alentados por los intelectuales de Latinoamérica, en el siglo XIX. Desde este punto de vista, la inmigración es vista como el mejor medio para la mejora de los hábitos y las costumbres (ver anexo histórico 1).

González (2004) explica que se busca traer desde afuera el progreso, porque se desconfía de las competencias del recurso humano local. El desarrollo y el progreso tecnológico son exclusivamente monopolizados por los países centrales y se supone que los recursos humanos más capacitados se encuentran en esos lugares (ver anexo histórico 2).

La concepción de las características de la modernización, cuyo inicio coincide con las políticas pro inmigración europea, se nutre abundantemente del concepto de "civilización” imperante en la época, de modo que, naturalmente, se estima que son los elementos foráneos quienes producirán los rasgos originarios del proyecto modernizador, que también busca estar bajo el amparo de la hegemonía de aquellas naciones que aparecen como modernas, con menoscabo de lo nacional, de las culturas locales, que no son consideradas aptas para emprender tamańa empresa (ver anexo histórico 3).

Uno de los móviles para promover la inmigración en Chile fue la necesidad de mantener poblados los extremos del territorio. Villalobos, en su Historia de Chile, escribe lo siguiente:

...en la misma época comenzaba a tomar importancia la inmigración europea hacia América a causa de los movimientos políticos que lanzaban a los desplazados a buscar nuevos horizontes y por la creencia generalizada y en gran medida verdadera de que era fácil hacer fortuna en estos países necesitados del esfuerzo y la técnica del europeo (1992, p. 237).

Recuerda Norambuena (1995), que el proceso selectivo para la inmigración era realizado por una Comisión, en la cual participaba Vicuña Mackenna, quien recomendaba al Gobierno las nacionalidades y prioridades que debían ser consideradas. Dice:

En primer lugar, "fomentar la llegada de alemanes por su carácter y por pertenecer a una raza especial que forma su patria en el bosque donde levanta su hogar u en el que ve crecer sus hijos libres y felices"; en segundo lugar, "a italianos y suizos porque se arraigan con rapidez, son buenos agricultores, afables, de clara inteligencia y provienen de una cultura genial".

En orden descendente recomendaba traer a los vascos por ser "sobrios y adecuados para el trabajo rudo" aunque no se establecían de manera definitiva; belgas por sus "dotes especiales para la industria"; 
ingleses (escoceses e irlandeses) haciendo la salvedad que eran viajeros o "transeúntes útiles" y no era esperable que se convirtieran en colonos. Los franceses, en términos generales, eran los "peores inmigrantes conocidos" pues siempre regresaban a su país, además que eran "vanos, poco dados a la familia y carentes de espíritu religioso". Los espańoles ofrecían desventajas por su "carácter altivo y dominante y de los cuales nada tenemos que aprender porque ellos ya nos han legado su sangre, lengua y sus costumbres como una herencia irrenunciable."

En este informe se dejaba expresa constancia que los chinos y negros eran inmigrantes no deseados en el país (pp. 80-81).

Existía una conciencia muy enraizada en los intelectuales chilenos, de que los europeos cristianos eran los inmigrantes mejor preparados para asimilar la idiosincrasia nacional y colaborar con el desarrollo del país.

Un caso particular lo constituye la inmigración planificada de colonos alemanes a Chile, la cual se distingue por esta y otras características de los flujos migratorios posteriores, que se caracterizaron por su espontaneidad. Se puede sostener que los colonos alemanes fueron parte de grupo audaz y vanguardista que se atrevió a sentar sus bases en una patria ajena y, más aún, en un Estado-nación que recién daba sus primeros pasos independientes.

Durante el decenio presidencial del general Bulnes (1841-1851), se llevó a cabo esta empresa de promover la inmigración de alemanes para colonizar los vastos terrenos del sur que se encontraban despoblados y, a la vez, ir concretando la ocupación de espacios ancestralmente pertenecientes al mundo mapuche. El deseo de promover el desarrollo, lo que requeriría aumentar la población, llevó a algunos a sostener que la inmigración era el más poderoso y rápido auxiliar de cuantos pudieran existir, para satisfacer tal necesidad y, con ello, el prestigio y la riqueza de la República.

En todo caso, el proceso de promoción de la llegada de inmigrantes europeos no estuvo exento de problemas y complicaciones, en particular, la resistencia de algunos sectores de la élite, para quienes la llegada de un contingente extranjero pondría en peligro el orden político y económico del país, lo cual produjo un potente debate que también incluía la definición de qué nacionalidad debía primar en esta empresa.

De otro lado, se debía contar con los elementos necesarios para hacer que los lugares potenciales de emigración elegidos por el Estado atrajesen a colonos aptos para emprender el poblamiento, cuidando que las noticias que llegaban a cada colonia ultramarina no fuesen contradictorias, evitando de este de modo que se difundiese información negativa de la gran empresa chilena. Por último, se debía conciliar la escasa existencia de terrenos aptos disponibles con la abierta disposición a entregar tierras sin costo a los colonos (Pérez Rosales, 1870).

Las dos últimas décadas del siglo XIx fueron el periodo de mayor esplendor de la comunidad alemana asentada en las regiones sureñas de Valdivia y Llanquihue. En octubre de 1850, Vicente Pérez Rosales asume el cargo de agente de colonización en Europa y dos años más tarde desembarca en Puerto Montt, con decenas de familias alemanas que se instalan a orillas del lago Llanquihue. Esta nueva oleada de inmigrantes transformó el paisaje natural del territorio, dedicándose a la agricultura, cuya 
producción se complementó armónicamente con las actividades fabriles y comerciales que realizaban los alemanes radicados en Valdivia.

Hacia 1870, el proyecto de colonización alemana del sur de Chile era exitoso: la región ostentaba el mayor dinamismo económico del país y los inmigrantes, con su espíritu emprendedor, constituían un mentís para aquellos que ponían en duda las bondades del asentamiento de foráneos en las despobladas tierras chilenas. Basado en dicho éxito, Pérez Rosales destaca que el inmigrante internacional es el factor más poderoso y rápido para aumentar la población de Chile, y lograr el asentamiento y desarrollo de terrenos inhóspitos y baldíos.

Siguiendo la tradición legalista que "desde siempre" caracterizó a la República, característica destacada por visitantes ilustres, aquel proceso planificado de inmigración se inició con una ley ${ }^{14}$, promulgada en 1845 , la cual, en palabras de Pérez Rosales, "adornada con la firma del guerrero y del estadista, manifiesta en claras y generosas cláusulas el modo y forma como debemos recibir, hospedar y fomentar en una colonia ese elemento de vida y de progreso" (1870, s/n).

Pero, es indudable que fueron muchas las vicisitudes de los pioneros en la nueva tierra, que se quejaban amargamente del clima, la lluvia, los vientos, la vegetación, en fin, todo aquello que caracteriza nuestra naturaleza austral. Esta situación queda de manifiesto en la cruda reflexión que el agente de colonización designado para la zona transmitía, mediante un oficio de diciembre de 1893 dirigido a su superior jerárquico, Pérez Rosales:

Han pasado miserias, hambres, trabajos, pero sin desmayar: todo lo debemos esperar de la cruda prueba a que ha sido sometida la constancia i la fe de estos infelices en el pasado invierno. Con semejantes elementos, si se aumentan, como es de presumir, veo ya seguro el próspero porvenir de la colonia, digan lo que dijeren sus injustos i miopes detractores $(1870, \mathrm{~s} / \mathrm{n})$.

Miquel (1863), en pleno debate sobre el impulso que debía darse a la inmigración externa en Chile, hace un análisis descarnado acerca de las dificultades de este proceso y de la falta de claridad, decisión e impulso gubernamental de tales políticas. Son elocuentes, al respecto, algunos párrafos de una interesante reflexión de este autor, en la cual hace el alcance de que el europeo no se vería atraído por Chile mientras existiese inseguridad de empleo, que coincide con la importancia que se otorgaba al trabajo como eje central de la vida, concepto unido indisolublemente a la modernidad y que influyó de manera determinante en la migración europea hacia Chile y también en la valorización de la planificación de los flujos migratorios. Dice este autor:

Suponer que un hombre abandone su patria, hogar i familia i se resuelva a trasladarse entre individuos de distinta raza i costumbres, por promesas

\footnotetext{
14 A propósito de este rasgo, persistente en nuestra historia y carácter, Gabriel García Márquez decía que Chile es el único país del mundo en donde las leyes se venden en los kioscos, a precios módicos, siendo notable que la gente las compre.
} 
brillantes i perspectivas halagüeñas, es una suposicion algo mas que aventurada i que dista mucho de ser un buen punto de partida para formular proyectos sobre la inmigracion europea (p. 7)

[...] Mil trabajadores estranjeros elejidos, pedidos i contratados bajo condiciones claras, esplícitas i determinadas, producirían mas trabajo i serian infinitamente mas laboriosos i útiles al país i a sus patrones que diez mil llegados a nuestras playas i ofreciendo su trabajo a las puertas de las casas, chacras i haciendas (p. 13).

Como hemos referido supra, las fuentes históricas son insistentes respecto de la escasa magnitud de la inmigración en Chile. En efecto, recordemos que en 1854, de una población próxima al millón y medio de personas, los extranjeros apenas llegaban a $20 \mathrm{mil}$, la mitad de ellos argentinos; $y$ los europeos eran alrededor de 6 mil, distribuidos casi en partes iguales entre británicos, alemanes y franceses (Blancpain, 1987 b, p. 193). En 1865, se registran en el Censo de Población 3.800 alemanes que se dedican, en orden de importancia, al comercio, la agricultura y las faenas marítimas; muy de cerca, con 2.800, les siguen los ingleses, entre los que destacan marinos, empleados particulares, mineros y comerciantes, y también hay carpinteros, herreros, mecánicos y fundidores. Algo parecido puede decirse de los inmigrantes franceses, que llegan a los 2.400. Llegados desde Italia se registran 1.000 personas, en su mayoría comerciantes y empleados particulares (Villalobos et al., 1976, pp. 613-618).

Entre 1882 y 1907, llegan a Chile unos 50 mil inmigrantes europeos, el $60 \%$ de los cuales arriba en 1889 y 1890 , dos ańos de alta inmigración. De estos inmigrantes, la mayor proporción, un tercio, eran espańoles, seguidos de franceses $(24,4 \%)$, italianos $(22,3 \%)$, suizos $(8,9 \%)$, británicos $(7,1 \%)$ y alemanes (6,6\%) (Blancpain, 1987a, p,. 194-196) (tabla 4).

En 1907, de poco más de 3 millones de habitantes, solo el 4,2\% eran extranjeros. Mientras, en Argentina, de una población de 4 millones de habitantes, 1 millón eran extranjeros, es decir, un 25\%; y en Brasil, de una población de 14 millones, un $17 \%$ eran extranjeros. Se observa, pues, la escasa corriente inmigratoria hacia Chile, aunque ello no se condice con el innegable impacto cultural que produjo.

En 1920, los extranjeros en Chile habían disminuido a 115 mil personas, lo cual obedeció a la considerable merma de peruanos y bolivianos producida, en gran medida, por el surgimiento de una nueva generación chilena nacida en territorios que habían pertenecido a aquellos países, y también merced a la incipiente paralización de las salitreras en Tarapacá y Antofagasta. Las únicas colonias que, en 1920, muestran un significativo aumento, son la española y la conformada por los árabes cristianos súbditos del antiguo Imperio otomano, que habían comenzado a llegar a fines del siglo XIX (Blancpain, 1987a).

Lo cierto es que durante todo este largo periodo, mientras el Estado proclamaba la relevancia de la inmigración, particularmente europea, los resultados no eran, cuantitativamente, los esperados. Ya a fines del siglo xIx, la Agencia de Colonización hace un descarnado análisis de la situación, no exento de autocrítica, que muestra a todas luces la dificultad de Chile para atraer un contingente poblacional 
de magnitud similar a las otras naciones de América, como Estados Unidos, Argentina ${ }^{15}$ e incluso la pequeña República del Uruguay, donde el crecimiento demográfico continuaba como consecuencia de la inmigración, mientras nuestro país solo recibía unas pocas centenas de 600 europeos por año, debido, entre otros factores, a que Chile no habría prestado atención debida al incremento de la inmigración europea como único medio de obtener un rápido poblamiento del territorio nacional (Vega, 1896).

De algún modo, la Agencia de Colonización pareciera sentirse sola en esta empresa. En efecto, según Vega, la Agencia preconiza el aumento de la población nacional mediante la inmigración europea con el fin de poder cubrir el extenso territorio, aprovechar los abundantes recursos naturales y de esta forma convertirse en una nación poderosa al igual, ejemplifica, que Suiza o Bélgica. Y hace notar las bondades de la inmigración que, además de producir mejoramiento de la industria manufacturera, proporcionaría un traspaso del conocimiento más avanzado de las sociedades europeas, específicamente en el ámbito agrícola (Vega, 1896, pp. 84-85). La Agencia insiste ante las autoridades nacionales en que si Chile se convierte, de verdad, en un país de inmigración podrá transformarse en una potencia mundial. Para lograrlo, propone criterios de selectividad que manifiestan clara preferencia por la inmigración europea y una perspectiva geopolítica que concibe la migración selecta pero abundante como necesidad primordial y elemento más beneficioso para un Estado en formación, cuya importancia y respetabilidad se basan en la secreta potencia de una gran población civilizada. Reafirma también la Agencia que la inmigración es el más poderoso factor del crecimiento demográfico de un país y que, en consecuencia, Chile debería colocar el mayor de los empeños en utilizarlo para tal finalidad. En este sentido, señala:

Un país nuevo, abandonado á los limitados esfuerzos de una escasa población nacional, progresa y surge talvez al fin de muchos ańos, pero su avance es lento, mezquino y apocado, y lo que pudo realizarse en corto tiempo, mediante el esfuerzo potente de una población abundante y preparada, se alcanza talvez, si se alcanza, en multiplicados lustros de constante batallar [...] cabe el gravísimo peligro de que á causa del desequilibrio entre la cifra de su población y la de los países vecinos, que se han cuidado de aumentar la suya aprovechando sabiamente la poderosa emigración europea, la nación imprevisora corra riesgo de la vida (Vega, 1986, p. 12) ${ }^{16}$.

Según Vega, la Agencia hace notar que el gasto que al fisco irroguen los inmigrantes constituye la mejor inversión que un Estado nuevo

\footnotetext{
15 Por ejemplo, entre mediados del siglo xIx y el inicio de la crisis económica mundial de 1929, Argentina recibió cerca de 6 millones de inmigrantes, mientras Chile solo unos 150 mil. En 1850, Argentina tenía 300 mil habitantes menos que Chile, pero hacia fines del siglo xIx lo doblaba en población y, en 1970, casi lo triplicaba.

16 Esta perspectiva geopolítica se plasmará en la política migratoria que aún rige a Chile, redactada en 1975, en plena dictadura militar (1973-1989).
} 
puede hacer de sus capitales. Y volviendo al argumento geopolítico, refuerza la idea de que en la inmigración reside la esperanza de un engrandecimiento mayor, que otorgue al país una apropiada posición internacional sudamericana. Ejemplifica con la vecina Argentina, que entre 1869 y 1893 había más que triplicado su población, gracias a la inmigración, y cuya producción agrícola se había incrementado en proporciones asombrosas. Y comparando nuestra situación con la de Brasil y Argentina la Agencia dice lo siguiente:

Ambos países con climas muy inferiores al nuestro, aprovechando su proximidad á Europa y movidos por una sabia comprensión de los beneficios de la inmigración, han alcanzado ya ventajas tales que nos adelantarán por algún tiempo, aunque desde ahora mismo quiera darse nuestra patria toda entera á la tarea de aumentar debidamente su población.

Podría argüirse talvez que el Brasil y la Argentina poseen grandes territorios, muchísimo más extensos que los de Chile; mas, si talvez pudiera presentarse ese argumento cuando Chile hubiera llegado al máximum de la población que puede contener, es totalmente insostenible en el momento actual en que le faltan todavía 35 ó 40 millones de almas para llegar á ese máximum. Y en seguida, completada esa gran población de que hablamos, ya veríamos si posible constituir una nación más poderosa que Chile de cada una de las ante-dichas repúblicas, considerando nuestra variedad de climas, algunos de ellos superiores á cualesquiera otros del mundo, la extensión de nues- tra costa y el número de nuestros puertos, colocados siempre al costado mismo del lugar de producción, la configuración del territorio en que alterna el valle con la montańa, la riqueza del suelo y la seguridad de abonarlo con producto propio, las fuerzas naturales ilimitadas de las caídas de aguas, la riqueza mineralógica unida á la agrícola, el vigor y la tenacidad de la raza que produce ese clima, la correcta organización política, etcétera (Vega, 1896, p. 13) ${ }^{17}$.

En fin, el reconocimiento oficial, por parte de las autoridades chilenas, de la necesidad de poblar y colonizar era evidente, a pesar de que, como se desprende de lo ya expuesto, los resultados demográficos fueron bastante menores a lo esperado. $Y$ es que las corrientes migratorias fluyen, como es natural, hacia regiones de población escasa, donde el suelo, el clima y otras circunstancias facilitan la vida y ofrecen la esperanza de la holgura y la riqueza; y, finalmente, razones de economía y de variada naturaleza explican que la emigración, si bien se dirige en un comienzo preferentemente hacia los países cercanos, en un segundo momento, cuando las distancias se acortan por la mejora del transporte y el mundo se amplía en las mentes de los potenciales emigrantes, aparecen nuevos lugares de destino. Es lo que ocurrió con los europeos que, en gran número, abandonaron sus tierras de origen para optar por nuevos destinos en el continente americano. Tal como lo indica el conocimiento acumulado sobre los

\footnotetext{
17 En todo caso, Vega nos señala que no solamente se trataba de atraer inmigrantes de corte empresarial, industrial y agrícola. Como, en gran medida, en el inconsciente de las élites dirigentes se identificaba la elevación estética con las culturas europeas, también se buscaba la presencia de cultores del mundo artístico.
} 
movimientos migratorios, estos dependen de las condiciones de vida en el lugar de origen, de las condiciones en el lugar de destino y de los medios de transporte disponibles para el traslado.

Chile era, desde fines del siglo XIX, un interesante lugar de destino. La Agencia de Colonización en Europa mostraba la necesidad de mano de obra calificada, y de técnicos y obreros en los más diversos oficios. La mayor dificultad era la carencia de recursos y de respaldo estatal para el transporte, pese a que mucha gente estaba dispuesta a hacer la travesía.

Según lo refiere Vega (1896), la crisis general que aquejaba en esos momentos a las naciones de Europa, despertó en muchos el anhelo de emigrar. Dice:

El hombre de paz y de orden se inclina siempre en este último sentido. Así, pues, en razón de la crisis económica general, del excesivo número de habitantes y de las legítimas aspiraciones que una civilización muy avanzada ha inspirado al obrero, á lo que cabría agregar todavía el peso abrumador de las contribuciones, el servicio militar obligatorio etc., ha venido creándose una fuerte disposición emigratoria en la masa de las poblaciones industriales, que raras naciones podrían aprovechar hoy día con más oportunidad y mayores beneficios que Chile (p. 16).

Respecto a la selectividad de la política migratoria, debe sostenerse que el privilegio otorgado a los eventuales emigrantes de Europa Occidental no significa preferencia por una nacionalidad específica.

Este criterio, muy relevante en cuanto a la formación cultural de Chile, contiene dos nociones básicas: de una parte, la preferencia por europeos y, de otra, la opción por una diversidad de naciones europeas, con la pretensión de aprovechar las virtudes de cada una de ellas. Al respecto, dice Vega:

Aquello que hace falta á la una lo posee en alto grado la población de la otra, así es como únicamente la resultante de todas juntas produce la civilización completa que se desea trasladar.

[...] De una inmigración exclusivamente inglesa, nadie podría exigir la excelencia del genio artístico francés, italiano ó espańol, y recíprocamente, estas nacionalidades por sí sólas muy difícilmente alcanzarían el alto espíritu de empresa y comercial, el genio mecánico y la tenacidad en la lucha con los elementos que caracterizan á la raza anglo-sajona.

[...] Por otra parte, la variedad de nacionalidades en la inmigración produce en poco tiempo la fusión de las razas inmigrantes, condición de éxito primordial de toda empresa inmigratoria conscientemente dirigida; y así esa población extranjera en los comienzos, se transforma con rapidez en una población exclusivamente nacional, unida en sus ideales y esfuerzos por la felicidad de una patria común.

[...] Más todavía: esa heterogeneidad de razas engendra el carácter democrático de la población; en tanto que siempre es difícil destruir, aún con muchos años de trabajo, los prejuicios y resabios políticos y á las veces autoritarios importados de las monarquías, cuando es una sola la raza que forma la corriente inmigratoria y tiene ocasión, por eso mismo, de conservarse exenta de alianzas extrañas de familia y de transmitir á dos ó tres generaciones las ideas y preocupaciones á que nos venimos refiriendo (pp. 20-21). 
El envío de emigrantes de nacionalidades diversas fue la regla constante de la Agencia de Colonización $^{18}$, aunque es manifiesto que se expresan preferencias: se opta por emigrantes, distribuidos en forma equivalente, de Francia, Alemania, España, Inglaterra, Suiza, Italia, Bélgica, Holanda, Austria, Suecia y Noruega. Incluso, Vega (1896) se pregunta cuál sería el actual nivel de desarrollo industrial y artístico de la América española, si en lugar de la exclusiva colonización hispánica las nuevas poblaciones se hubieran formado con inmigrantes de las diversas nacionalidades europeas, por partes iguales.

La mirada comparativa desde Chile hacia Argentina es permanente. En dicho país, se llevó a cabo un proceso migratorio concentrado mayoritariamente en una nacionalidad, la italiana. Vega sostiene que dicha opción es negativa para la consolidación de las nuevas naciones, aunque reconoce que "á pesar de estos gravísimos defectos, representa esa inmigración una población humana europea que ha producido al país que la hospedera enormes beneficios, de que este habría carecido si esa población no se hubiese radicado en su suelo" (1896, p. 79). En cambio, Chile actúa en forma totalmente opuesta y favorece una inmigración europea de índole multinacional. Vega sostiene que la inmigración europea es saludable y bienvenida, siempre y cuando permita conservar intacta nuestra naciona- lidad y actual raza, para lo cual propone: a) crear gradualmente una corriente inmigratoria europea con pluralidad de nacionalidades; b) buscar por todos los medios posibles que los inmigrantes opten por adquirir la nacionalidad chilena; c) identificar inmigrantes con vocación industrial; y d) propender por el equilibrio y la armonía entre aquellos inmigrantes, tanto en pos del progreso científico como del artístico.

Reveladoras resultan las palabras de este autor cuando analiza las características de las nacionalidades de la población que debiese asentarse en Chile, manifestando una clara opción por la multiculturalidad, pero solo europea. Aunque estemos frente a una visión amplia y estrecha al mismo tiempo, esta aproximación, que corresponde a la mentalidad compartida en la élite, permite colegir una de las bases de nuestra hipótesis, que consiste en sostener la existencia de una multiculturalidad chilena bastante más prolífica y asentada que la que exhibe la mayor parte de nuestra historiografía, que postula una supuesta primacía de la homogeneidad cultural. Esta multiculturalidad se acrecienta con las bondades de la migración que llega posteriormente, sobre todo desde Asia, Oriente Medio y la Europa eslava.

Vega es aún más preciso en su opción multicultural solo europea, al señalar qué grupos de emigrantes debiesen llegar a Chile,

\footnotetext{
18 Se entrega una detallada relación de envío de emigrantes entre 1883 y 1896. En total son 31.139. El mayor porcentaje corresponde a españoles, con un 31,2\%; luego franceses, con un 23,9\%; suizos, con un 9,6\%; ingleses, con un 5,9\%; y alemanes, con un 4,7\%. Otras nacionalidades corresponden a un $27,7 \%$ (elaboración del autor sobre la base de Vega, 1896).
} 
apuntando, por un lado, a la familia de pueblos germánicos y, por otro, a la greco-latina, cuya población total no superaba los cien millones de personas. Puesto que, a nuestro juicio, refleja muy apropiadamente el pensamiento de la época en torno a las migraciones y las preferencias culturales, me permito citar in extenso el razonamiento de Vega, que constituye un importante punto de inflexión en cuanto se refiere a las nociones que contenía el imaginario social eurocéntrico -homogeneizador y plural selectivo- desde la mirada chilena:

Entre ambas [naciones] se divide por mitad la población del mundo europeo occidental. Partiendo, pues, de estos antecedentes, se trata ahora de resolver si la población chilena del porvenir deberá ser germana ó latina, ó en otros términos, si nuestra inmigración será exclusivamente reclutada aprovechando las buenas condiciones y padeciendo los males de una sola de las dos razas que se dividen por mitad la población de los países europeos de emigración.

Entre germanos y latinos, que se encuentran como se ha visto, en una misma proporción en Europa, lo concreto de la cuestión no deja dudas sobre la resolución: antes que germana, la enorme mayoría de los chilenos (hoy exclusivamente latinos) preferirían latina, como ellos, nuestra raza del porvenir; pero al mismo tiempo, todos los chilenos desearían poseer tantas excelentes condiciones exclusivas de la familia germánica.

Parece, pues, que no deberíamos propender á ser germanos ni latinos, sino chilenos constituidos por aquellas dos grandes razas europeas, ó más concretamente, que nuestra inmigración debería ser mitad germánica y mitad latina.

El poblamiento de nuestro país se realizaría con la concurrencia simultánea de los antedichos elemen- tos, elegidos en cada uno de los principales países de emigración. Ni la nacionalidad única, ni la raza única deben, en caso alguno, constituir nuestra inmigración.

Ello importaría para nosotros ese desequilibrio etnográfico que ha producido en otros países los yankees anglo-alemanes, los canadienses anglo-franceses. Los australienses anglo-sajones, los argentinoitalianos y aún los mismos hispanoamericanos.

¿Quién no divisa que por un procedimiento tal es una sola ó dos cuando mucho la civilización incompleta, imperfecta que se traslada y desenvuelve en la comarca ó país que recibe la emigración, y la falta que allí se advierte de los demás elementos civilizadores poseídos por otras razas ó naciones europeas?

¿Quién ignora que cada país europeo tiene sus cultivos especiales, apropiados á su clima y sistemas de cultura diferentes, casi todos utilizables en el suelo y bajo el clima incomparable de Chile? ¿Por qué entonces descuidar el aprovechamiento de todas y cada una de tan diferentes aptitudes industriales?

Por eso, reconociendo en cada raza sus cualidades especiales, es de todo punto inconveniente excluir una por las otras, absorbiéndose, por ejemplo, en la contemplación de la soberana de los mares, la primera potencia marítima del globo, ese opulento banquero, fabricante y mercader de todo el universo, la poderosa nación inglesa, cuya raza puebla ya tantas regiones: ni en la de la Grecia moderna, foco del arte y de las artes, de la ciencia y de las letras, y verdadera síntesis la civilización contemporánea, la bella Francia; ni en la de esta nación de sabios, de filósofos atrevidos, de población instruidísima, industrial poderoso, negociante activo y hacendista emprendedor, la potente Alemania.

No: ni franceses, ni ingleses, ni alemanes; ni germanos, ni latinos: chilenos, herederos de esas razas y de los frutos selectos de su civilización, han de ser los futuros pobladores de nuestra patria.

OASIS, N²2 -Julio-Diciembre $2015 \cdot$ pp. 49-91 
Desde muchos años atrás se ha visto particularmente combatida en nuestro país la inmigración española, á virtud de prejuicios poco explicables. Como inmigración exclusiva es claro que sería inferior á la exclusivamente francesa, inglesa ó alemana, y superior con mucho á la italiana; pero en concurrencia con las demás razas y nacionalidades europeas que forman y deben formar siempre la corriente de la emigración hacia Chile, enriquece la masa emigratoria con elementos excepcionales que faltan ó escasean en las otras nacionalidades. Desde luego, como ya lo insinuamos mas atrás, el clima de España, aunque más extremoso que el de las regiones centrales chilenas, tiene mucha semejanza con él. De ahí proviene que la totalidad de los cultivos españoles son aprovechables en nuestro suelo (1896, pp. 144-148).

Con todo, a pesar del inmenso esfuerzo por poblar nuestro territorio, bajo la opción por la inmigración plural europea, la cantidad de inmigrantes que recibió Chile fue modesta, a diferencia del óptimo resultado demográfico obtenido por países que optaron por atraer una o dos nacionalidades. La mirada oficial chilena señalaba que las ventajas de aquella opción eran muchas, entre ellas las siguientes: a) la rápida eliminación del carácter extranjero de la población inmigrante y su chilenización, lo que sería imposible de conseguir colonizando con una sola nacionalidad; b) el aprovechamiento simultáneo de las condiciones intelectuales, morales y físicas de cada una de las principales razas y naciones europeas, que permitiría la rápida formación de una población exclusivamente chilena, pero heredera de aquellas condiciones; c) la generación de intercambio de productos con casi todos los países europeos que prefigura, en una época de globalización solo incipiente, los intereses del futuro global que vendrá en los próximos cien años. Por estas razones, la inmigración se focaliza en torno a tres ejes fundamentales: europea, plural y proporcional (Vega, 1896, pp. 60-62).

\section{El ideario nacional de CHILE y LoS INMIGRANTES EN LA ERA DE LA MODERNIDAD}

La manera como se asimilaron los inmigrantes de la modernidad en Chile es un tema que genera divergencias. Por un lado, existe evidencia de que lograron integrarse adecuadamente, hasta el punto de fundirse en nuevas identidades $^{19}$; por otro, se aprecia que las distintas comunidades de inmigrantes asentadas en ese periodo han logrado, con distintas intensidades, mantener costumbres y rasgos culturales ligados a sus orígenes, porque habría predominado la voluntad consciente de diferenciarse de la sociedad chilena.

Es interesante seguir la mirada de Vega (1896), que seguramente coincide o es muy cercana a la oficial, sobre la fusión cultural de los inmigrantes europeos. Al aplicar tal visión, se deseaba reconvertir rápidamente a estos inmigrantes en ciudadanos chilenos. Pero era natural la propensión de estos nacionales a

\footnotetext{
19 En el proyecto Unesco, en el cual el autor de este trabajo participó como investigador (ver Agar y Rebolledo, 1997), la idea central era evidenciar la exitosa integración de los inmigrantes y descendientes árabes en países de América. Sobre esta idea también discurre el trabajo sobre cohesión social de la comunidad árabe en América Latina (Agar, 2014).
} 
mantener rasgos culturales propios, tales como el idioma, la religión, las costumbres. Puesto que la educación era el factor clave para dirimir esta tensión, Vega releva la controversia sobre qué tipo de maestros, si extranjeros o chilenos, debían tener las escuelas en los nuevos centros de asentamiento de colonos. Se argumenta, de un lado, que el maestro extranjero podría enseñar en la lengua materna, facilitando el aprendizaje; pero, del otro, se afirma que esa fórmula produciría una anomalía que "dificulta en gran manera, por medio de esa suerte de prolongación de la patria que el colono acaba de abandonar, la chilenización de los niños, propósito capital de la colonización” (p. 159).

La idea básica que prima en el ambiente de la época, en cuanto a la inmigración colonizadora, apunta a una rápida asimilación por la vía de la nacionalización, para que los migrantes adquieran la tranquilidad de sentirse en un suelo patrio. En cambio, sobre la base del mismo criterio homogeneizador que prima desde los inicios del proceso migratorio en la modernidad, se advierte que la enseñanza a cargo de los extranjeros, incluidos los propios colonos, conduciría a separar a sus hijos de la población chilena y a constituir colectividades cerradas, opuestas a la formación de un Estado nacional unitario que, a lo menos, disimulase las diferencias. Dice Vega al respecto:

Se comprende, pues, que uno de los medios más eficaces y más equitativos para allanar estos obstáculos en cada colonia, es la creación en ellas de escuelas nacionales, con maestros nacionales, preparados por los distinguidos pedagogos de nuestras escuelas normales con tanta perfección como los mejores del mundo, sin excluir á los alemanes ni á los suecos.
[...] El maestro nacional chilenizará seguramente los hijos de los colonos; les dará una instrucción tan perfecta como la mejor que habrían podido adquirir en Alemania ó Suecia, y muy superior á la de otras naciones, y les enseñará un idioma común para sus relaciones con los otros colonos extranjeros y los nacionales del suelo en que van á radicarse para siempre.

[...] Un preceptor extranjero haría todo lo contrario: combatiría directa o indirectamente toda tendencia de chilenización, sus propios sentimientos lo inclinarían virtualmente en ese sentido; no podría dar á sus discípulos una instrucción superior á la del maestro chileno, y le sería imposible enseñar una lengua por él ignorada ó mal sabida, como el castellano (pp. 159-160).

En dicho contexto, se plantea en forma transparente que los maestros, curas o médicos extranjeros al servicio de las colonias son elementos contrarios a la chilenización de los descendientes de los colonos, motivo por el cual tales servicios, en general, debiesen ser encomendados exclusivamente a chilenos. Se aprecia claramente que la apuesta es a la integración asimilacionista de los hijos de colonos nacidos en Chile, aunque la primera generación de descendientes queda entre dos mundos: el de la patria originaria de sus padres, que transmiten el sentimiento de pertenencia y pérdida, y el medio local nativo, que les presiona para que se incorporen rápidamente a la cultura de acogida.

Por su parte, Zavala (2008) apunta que los inmigrantes franceses, alemanes y británicos vieron en la educación un pilar fundamental para el mantenimiento de sus valores ancestrales y hace ver que los primeros inmi- 
grantes europeos instalados en las colonias rurales de la Araucanía debieron resolver por sí mismos cuestiones de índole económica, social y cultural propias del asentamiento en una nación lejana y en plena construcción de su identidad nacional. Ellos requerían, a la vez, crear las bases logísticas necesarias para la habitabilidad y la explotación agrícola de sus hijuelas y construir los soportes de una vida social dotada de "sentido", a partir de sus propios referentes culturales. En este último aspecto, era vital crear espacios de encuentro y conservación de la "identidad" y de la "vida comunitaria" originaria, pero también otros que pudieren plasmar un proyecto de futuro, en particular para los hijos.

A su vez, Bucher (2001) ha insistido en forma documentada que fueron los descendientes de los inmigrantes quienes pudieron incrementar la capacidad empresarial, debido a que la inmigración pionera había tendido a mimetizarse con los estratos del bajo pueblo. Asimismo, sobre la base de antecedentes de archivos históricos y relatos de viajeros, este autor desmiente la idea de que los inmigrantes europeos eran en su gran mayoría comerciantes, empresarios o empleados prominentes que desarrollaron una movilidad social ascendente. Si bien compartimos esta visión de los empresarios pioneros como desprovistos de capital, estimamos que ellos y sus descendientes de primera generación sí pueden ser calificados como emprendedores - de hecho es posible equiparar emigrar a emprender-, sin capital económico ni social, pero dotados de la energía originada por la nueva oportunidad que les daba la vida para cambiar drásticamente su situación social. Es pertinente, pues, catalogarlos como "empresarios", no por su origen social o el aporte de capital financiero, sino atendiendo a su mentalidad, de modo que, en términos sociológicos, se puede hablar de un capital cultural que se incrementa y se hace visible cuando, tras el paso de sucesivas generaciones descendientes, se produce la integración con las élites dominantes precedentes. De esta forma, el capital cultural se transforma capital social, amplificando las redes sociales y esas relaciones de confianza tan necesarias para el progreso en el trabajo comercial e industrial que caracterizó a esos inmigrantes, en los inicios de su vida en Chile.

El bajo número de inmigrantes que llegó a las distintas zonas de Chile no fue suficiente para provocar un impacto demográfico, pero aun siendo reducido en número, es reconocida la influencia de aquellos extranjeros, tanto en la formación como en el desarrollo de la sociedad chilena. El ejercicio de esta influencia y la rápida asimilación de las costumbres nacionales se deben, en gran parte, a dos realidades: el deseo estatal de promover la llegada de hombres emprendedores, capaces de contribuir al proceso de desarrollo del país, y la motivación de quienes llegaban, buscando un nuevo horizonte, por construir una vida nueva y mejor, en un territorio virgen y fastuoso, libres de cualquier amenaza o acoso.

En consecuencia, los actores del flujo inmigratorio entre la segunda mitad del siglo XIX y la primera del siglo xx tuvieron una rápida y exitosa inserción, vinculándose en un tiempo relativamente breve con la élite local, a través de un proceso de movilidad social ascendente. Desde entonces, no han dejado de tener un 
papel preponderante en el desarrollo de la economía nacional (García, 2009) ${ }^{20}$.

Lo anterior explica los datos que proporcionan Mattelart y Mattelart sobre la participación de la población extranjera en la economía nacional, en proporción inversa a su peso cuantitativo. Refieren: "En 1936, el número de extranjeros alcanzaba el $2 \%$ de la población; sin embargo eran dueños de $20 \%$ de los establecimientos económicos. En 1940, el $18,9 \%$ de las industrias estaban en manos de los extranjeros. Y eran propietarios del $19,3 \%$ de los establecimientos comerciales" $(1965 \text {, p. 82 })^{21}$.

La rapidez con que, merced a su carácter emprendedor y decidido, muchos inmigrantes $\mathrm{y}$ descendientes pasaron a formar parte de la élite nacional, los transformó en importantes agentes del desarrollo del país. En todo caso, si bien el éxito económico y social, obtenido a no mucho andar, proporciona un antecedente importante sobre su exitosa integración en la sociedad chilena, no es un indicativo determinante para explicar su "integración plena" a una sociedad nueva, la cual no se puede establecer solo en función del éxito económico, laboral o social que tuvieron aquellos casos exitosos. Por tanto, hay que indagar más allá del factor económico, discerniendo cómo fueron afectados por las contingencias sociopolíticas de cada tiempo y, también, los niveles de emotividad y nostalgia que quedaron impregnados en la memoria de las primeras generaciones, sin minusvalorar historias particulares que se tejen en lo más profundo de los sentimientos, en las redes familiares y en los círculos más cercanos. La realidad obliga a admitir que la integración a una sociedad con fuerte sesgo asimilacionista, como era la chilena, fue un proceso complejo y contradictorio; doloroso, porque implicaba dejar atrás toda una vida, $y$ esperanzador, porque permitía volver a nacer y comenzar de nuevo.

Las migraciones en la modernidad no respondieron solo a criterios poblacionales, sino también, como hemos visto, a una ideología imperante que privilegiaba el ingreso de personas y familias con ciertos rasgos culturales y étnicos que se adaptaran rápidamente a las necesidades de las élites de la época y su paradigma de desarrollo, los cuales se identificaban primariamente con extranjeros provenientes de Europa. El objetivo contemplaba, por cierto, poblar territorios de baja densidad demográfica, aumentar el tamaño de la población y desarrollar la agricultura e industria, pero también incluía consolidar el imaginario de un pueblo chileno marcado, por un lado, por el influjo cultural europeo y, por otro, sumido en la convicción de que la diversidad de la

\footnotetext{
20 En un análisis de apellidos de la población residente en Santiago (año 2008), se encontró que un 16\% tiene al menos un apellido no español; y que un $10 \%$ no lleva apellido, ni materno ni paterno, español. Sin embargo, en el análisis de parlamentarios (año 2010) esta cifra cambia sustantivamente: un $42 \%$ tiene al menos un apellido no español y un $34 \%$ no lleva apellido materno o paterno español. Esta diferencia muestra la importancia de la presencia, en el poder político, de los descendientes de los inmigrantes europeos y árabes, lo cual también se refleja en otras áreas de las actividades económicas o profesionales (Agar, 2011).

21 Texto original en francés. La traducción al español es responsabilidad del autor de este trabajo.
} 
inmigración europea se fundiría rápidamente en la chilenidad, sin producir fisuras en la conformación de un pueblo homogéneo.

Con todo, a pesar de que las comunidades inmigrantes mantuvieron sus identidades étnicas en mayor medida de lo que sugerían visiones excesivamente optimistas sobre su asimilación por la cultura local, debe recordarse que la necesidad de mano de obra produjo una más fluida integración de los inmigrantes en la sociedad receptora, incluso considerando la marcada diferencia entre quienes correspondían a parámetros étnicos deseados y otras comunidades que fueron resistidas por sus orígenes nacionales o religiosos. En la mayor o menor aceptación de los inmigrantes modernos también influyó si constituían o no contingentes contemplados en las políticas manifiestas de colonización promovidas por el Estado, con las consecuentes facilidades para su asentamiento territorial y su inserción social y económica. Sabemos que inmigrantes externos espontáneos (europeos, árabes o chinos, entre otros) que llegaron durante la era de la modernidad, debieron hacer frente a una sociedad que los discriminaba por su origen étnico y condición social. De todos modos, insistimos en que la disposición de ánimo de unos y otros inmigrantes, que buscaban con vigor una nueva patria, fue fundamental en el proceso de integración a Chile.

Es evidente que los elementos determinantes para las políticas de poblamiento de nuestro país han sido variados. El espíritu de la época fue determinante en el discurso de la homogeneidad. Hoy día, empero, no podemos permitirnos omitir que los inmigrantes que llegaron durante la modernidad, con sus costumbres y espíritu emprendedor, hicieron un inmenso aporte al desarrollo de Chile y son parte de nuestra cultura.

\section{CONSIDERACIONES FINALES}

Hasta la década de los setenta, Chile sufrió pérdidas poblacionales debido a la emigración, principalmente hacia Argentina (por razones económicas) y luego diversificada hacia otros países, fundamentalmente por razones de exilio político. En los años noventa, disminuyó este flujo hasta lograrse casi un equilibrio poblacional debido al crecimiento económico y a la reinstauración de la democracia. Es a partir de este suceso histórico, al que se suman progreso económico y estabilidad política, que se inician nuevas migraciones, mayoritariamente sudamericanas, con ímpetu nunca antes conocido (tabla 1).

Como se desprende de todo lo dicho, las migraciones internacionales se inician en Chile desde el momento en que el territorio es conquistado por los españoles y, a partir del choque de civilizaciones que significa, comienza un encuentro de culturas que forjará nuevas realidades humanas, las cuales, en el largo plazo, se traducen en una nueva nación, fenómeno que también acaece en el resto del continente.

Cómo se asimilaron los inmigrantes modernos en Chile es un tema que genera divergencias que hemos revisado en el apartado anterior. Por un lado, se puede sostener que esas migraciones lograron integrarse adecuadamente, hasta el punto de fundirse en nuevas identidades; pero, por otro, se puede apreciar que las comunidades de inmigrantes han lo- 
grado, con distintas intensidades, mantener costumbres y rasgos culturales ligados a sus orígenes.

Con todo, a pesar de tal persistencia identitaria, que superó las expectativas más optimistas sobre la asimilación de inmigrantes, recordemos que la actitud abierta de las sociedades receptoras, debido a la necesidad de mano de obra, facilitó su integración, y también, la pertenencia a contingentes contemplados por las políticas de colonización estatales jugó un papel preponderante en la aceptación de los inmigrantes.

El desafío de Chile en esta nueva era de migraciones consiste en la apertura social y mental hacia una sociedad plural y dialogante, desde el ángulo cultural, basada en el nomadismo y las identificaciones múltiples. Se trata de transitar hacia una sociedad inclusiva que acoja, reconozca e integre con mucha fuerza a la gente que no pertenece al "topos" -lugar- para así construir la "u-topía”, aquello que trasciende el lugar, de una sociedad más diversa y tolerante. El lazo dialéctico entre el necesario sedentarismo y la pulsión del "otro lugar", polos que tensionan la sociedad posmoderna, puede y debe constituirse en potente motor de una sociedad renovada, marcada por influencias culturales variadas y por el empuje de nuevos grupos humanos. Más allá de resquemores y temores de unos y otros, el encuentro de culturas, a la larga, siempre enriquece pues contiene la fuerza de un renacer en los inmigrantes y, por parte de quienes acogen, la lucidez para reconocer la necesidad de nueva savia en las raíces forjadas.

Para Maffesoli (2004), la mirada exterior, desde fuera, posee una visión más penetrante, más ácida también, pues permite ver lo que para ojos demasiado habituados es difícil apreciar. Dice:

Las culturas en sus momentos fundadores supieron pasar por el crisol de su tradición los múltiples aportes del extranjero. Y cuando desean conservar su dinamismo eso es lo que hacen de nuevo. En este sentido, la vida cotidiana, en su aspecto estático, no es más que una perpetua integración, consciente o no, de lo que viene de lejos (p. 109).

En nuestra historia, encontramos un sinnúmero de experiencias vitales, tanto de comunidades extranjeras cuanto de individuos, que han permeado las rigideces de lo social, actuando como una suerte de detonantes de encuentros culturales fructíferos que, lenta pero consistentemente, han ido construyendo en el imaginario colectivo una sociabilidad que ha superado los límites de las relaciones formales. En estos casos, tal energía subterránea de la diversidad ha superado, en fuerza y magnitud, a la tentación aún presente de uniformidad. Así, nuevamente aparece la diversidad cultural comunitaria como un nítido aporte a la formación de una nación nueva y potente, aunque persistan dificultades para aceptar tal diversidad y permanezca latente la idea de que nuestro desarrollo se ha basado exclusivamente en la integración asimilacionista de diversas culturas - extranjeras u originarias- a lo largo de la historia independiente de Chile.

La sociedad moderna ha girado en torno al trabajo, como aquella actividad humana que es sostén de todas las demás, de modo que no es de extrañar que las migraciones internacionales que hemos recorrido en Chile tuviesen como 
motivación central de atracción ese factor. Chile en particular, y el continente americano en general, disponían de tierras baldías y escasa población, lo cual explica que las migraciones que se inician en el contexto de la emergencia de la modernidad europea llevasen el signo del trabajo. Empero, en las nuevas migraciones externas de la posmodernidad, si bien el factor laboral está presente, ya no es el único que cuenta en la decisión de emigrar o de permanecer en los lugares de destino.

Hoy, aunque las fronteras siguen presentes, los contactos entre culturas tienen cada vez más espacio, y una reconstrucción del significado de las fronteras, como puntos de interacción, estimulará cada vez más procesos plurales, desde una mirada intercultural. El paso de la mera consideración de lo social formal, de la unicidad monocultural en la construcción de la nación, hacia una mirada pluricultural que abarque la diversidad de aportes y legados de los migrantes internacionales, tanto en la modernidad como en la posmodernidad, también permitirá avanzar en aquel sentido.

Los nuevos flujos migratorios imprimirán un punto de inflexión en ese Chile marcado por una impronta identitaria caracterizada históricamente por el desconocimiento de lo diferente e, incluso, por el olvido sistemático de sus raíces indígenas, que son parte de nuestro mestizaje original. Los nuevos inmigrantes, de todos los colores, ritmos y creencias, nos están obligando, por fin, a repensar el paso desde nuestro sesgo monocultural, basado en la noción de Estado-nación dominante en prácticamente toda nuestra historia independiente, hacia el reconocimiento de lo multicultural -tanto de los pueblos originarios como de las comunidades migrantes de la posmodernidad y los descendientes de aquellas de la modernidad- con una mirada basada en el diálogo entre las culturas.

La cohesión social es un proceso de reconocimiento recíproco entre subjetividades, fundado en la referencia común a modelos socialmente aceptados. Existe una confluencia entre las metas culturales, las oportunidades existentes y la formación de capacidades para alcanzarlas (capital social). En tal sentido, el aporte cultural de los inmigrantes y sus descendientes ha significado un inmenso aporte al desarrollo del país, en su historia republicana. Con todo, los caminos de inserción y visibilización cultural han sido complejos, $y$ tenido hasta hoy escaso reconocimiento en la formación de la sociedad chilena, aun cuando Chile se encuentre en proceso de validación de la pluriculturalidad. Por lo mismo, es necesario avanzar con rapidez hacia mayores grados de comunicación entre las distintas culturas comunitarias. Una plena cohesión social de inmigrantes o sus descendientes vigorizará la sociedad chilena en sus dimensiones sociales, económicas y culturales.

Uno de los principales desafíos en materia migratoria y de pluralidad cultural consiste en generar condiciones de inclusión. Hay mucho por hacer, no solo con los inmigrantes, sino también con las comunidades originarias de países sudamericanos, principalmente de Argentina, Bolivia, Colombia, Ecuador y Perú, que suman a un número importante de descendientes - chilenos, pues han nacido en nuestro suelo- hijos de inmigrantes o producto de uniones mixtas. Los descendientes son parte de una comunidad, en la medida 
que mantienen sintonía con sus raíces y se cohesionan cuando logran el justo equilibrio entre el vínculo emocional que los une a sus orígenes y la sociedad de acogida. Para forjar un ethos en que la nacionalidad no sea criterio excluyente sino elemento reconocedor de la adscripción a distintas culturas, el trabajo ha de ser perseverante, muchas veces silencioso. Este es el signo de los nuevos tiempos.

Hay voces que han alertado sobre la experiencia europea y el tratamiento de los asuntos migratorios. Por muchas razones, el caso chileno no puede asimilarse a la experiencia europea en tales asuntos, pero debiésemos estar alertas en la búsqueda de armonía comunitaria, con la mirada puesta en la construcción de una sociedad pluricultural.

La experiencia con las comunidades descendientes de la inmigración europea y árabe de los siglos xIx y xx, que hemos analizado, ha sido generosa y exitosa, a pesar de las vicisitudes propias de la época. Sus descendientes, hoy en tercera y cuarta generación, han mostrado un proceso positivo de integración, aportando al desarrollo en variados ámbitos. En todo caso, en estos grupos comunitarios se impuso una tendencia a la "chilenización", como consecuencia de la necesidad de vigorizar el incipiente Estado-nación, enfoque que hoy debiese ser sustituido por otro que busque la cohesión pluricultural, aunque sin perder la visión de nación unitaria. La identidad nacional saldrá fortalecida con el reconocimiento de la diversidad.

\section{ANEXOS TEXTOS HISTÓRICOS}

\section{ANEXO 1. SOBRE LA INMIGRACIÓN ${ }^{22}$}

Es necesidad primordial de un Estado en formación, la corriente inmigratoria selecta y abundante. No hay elemento que como este pueda producir más altos beneficios en los países nuevos; ni hay sacrificio que no sea obligatorio sobrellevar para conseguirlo. Esa secreta potencia que determina la importancia y la respetabilidad de las naciones no es otra que una gran población civilizada.

Y este bien supremo para un Estado nuevo, del cual depende su engrandecimiento y poderío, lo procura la inmigración juiciosa y sagazmente establecida, si el suelo y el clima y demás condiciones del país permiten la constitución de una nacionalidad. Estados Unidos y Australia comprueban esta verdad; y en más reducidas proporciones, Méjico y las repúblicas sudamericanas.

A primera vista parecería inoficioso demostrar la utilidad y la necesidad de la inmigración, fuérzanos, sin embargo, á ocuparnos en ella la consideración de que hay quienes la combaten en nuestro país y aún pretenderían eliminar esta empresa de nuestros servicios públicos.

Un país nuevo, abandonado á los limitados esfuerzos de una escasa población nacional, progresa y surge talvez al fin de muchos años, pero su avance es lento, mezquino y apocado, y lo que pudo realizarse en corto tiempo, mediante el esfuerzo potente de una población

22 Reflexiones de la Agencia de Colonización en París (Vega, 1896, pp. 12-23). 
abundante y preparada, se alcanza talvez, si se alcanza, en multiplicados lustros de constante batallar.

No es todo: cabe el gravísimo peligro de que á causa del desequilibrio entre la cifra de su población y la de los países vecinos, que se han cuidado de aumentar la suya aprovechando sabiamente la poderosa emigración europea, la nación imprevisora corra riesgo de la vida.

Por lenta y costosa que aparezca en los comienzos, es su importancia tal y sus resultados tan ciertos, que el provocarla y desenvolverla es ineludible obligación de todo Estado nuevo. Cuanto dinero invierta el fisco en empresa semejante contribuye al cabal cumplimiento de una de las más altas misiones del Estado como entidad política: proveer al aumento necesario de la población nacional. Los caudales públicos gastados en inmigrantes son la inversión más productiva que puede hacer de sus capitales un Estado nuevo. Gobernar es poblar, dijo para Sud-América un estadista americano, y para Chile es hoy este problema y será durante largos ańos la obra más considerable de que deberán vivir pendientes todos los políticos nacionales.

Mientras tanto la inmigración ha dejado de ser un problema para diversos países. Sin recordar á los Estados Unidos y la Australia, que deben su progreso gigantesco exclusivamente á la inmigración, el Brasil y la República Argentina, Méjico y el Canadá nos muestran en proporciones más modestas las ventajas de este crecimiento artificial en los comienzos, y enteramente natural y espontáneo cuando la corriente se halla establecida. La República Argentina, que en 1869 tenía 1.400 .000 habi- tantes, en 1893 había más que triplicado esta cifra: 4.500.000 habitantes.

Tenga Chile 40 millones de habitantes, y entonces invitaremos á la discusión, cuando sus cultivos intensivos y su porvenir de país manufacturero se vean realizados. Mientras tanto, si posee con exceso vastos territorios inhabitados, que venga la población á explotarlos y á completar con los años aquella anhelada cifra.

Es de toda necesidad elegir emigrantes no solamente en todas las naciones civilizadas de Europa, sino en todas las clases industriales y artísticas. Por eso censuró mal quien se dio la tarea de combatir el envío de modistas y sombrereras escogidas en Francia: esa gente es la que importa el arte de vestir en que se invierten tantos dineros constantemente en Chile; esa gente es la que contribuye á formar el buen gusto indispensable en cualquier país y sin el cual podrá siempre tildársele de imperfecto ó incompleto; esa gente es la que forma el núcleo artístico de los prósperos talleres que tienen hoy mismo ya las grandes casas comerciales de Santiago y Valparaíso, en los cuales se confecciona mucho de lo que antes se importaba.

$\mathrm{El}$ arte no reside únicamente, como algunos muestran suponerlo, en las cuatro grandes ramas de las bellas artes, la pintura, la escultura, la arquitectura y la música; el arte lo toca todo, y este indispensable coronamiento de la civilización debe embellecer cuanto el hombre piensa y ejecuta, desde la más alta concepción sociológica hasta la última pieza de una máquina.

Todo lo dicho prueba sin contestación posible la necesidad premiosa que experimenta la República de procurarse al punto una vasta co- 
rriente inmigratoria que fomente la industria, colonice, y aumente con rapidez la población.

Esta corriente humana afluye, como es natural, hacia las regiones de población escasa, en las que el suelo, el clima y otras circunstancias facilitan la vida y ofrecen la esperanza de la holgura y la riqueza. Razones de economía y de otra naturaleza influyen, finalmente, en que la emigración se dirija al principio con preferencia hacia los países cercanos de los centros emigratorios. Y así se llega á ver fácilmente que son tres los elementos principales á que debe atenderse en el estudio de este proceso social. Primeramente, á la existencia de población emigrante; en segundo lugar, á las condiciones del país de inmigración y en tercero, á la distancia entre este país y los centros de emigración.

\section{(Primer asunto) Existencia en Europa de pobla- ción emigrante.}

La emigración europea es un hecho que manifiesta la estadística, del que ya hicimos caudal oportunamente y que nadie puede revocar en duda.

No hay país perfecto, es decir, que contenga en selección todos los elementos superiores que posee la humanidad. Las más altas manifestaciones del progreso de la especie humana no se han centralizado en Estado alguno; se encuentran repartidas en casi todos ellos, y muy especialmente entre los de la Europa Occidental.

Así, pues, el estadista chileno que desee para su patria una corriente inmigratoria elegida, capaz de transportar al cabo de los años la civilización moderna verá obligado á provocarla simultáneamente en todas ó casi todas las naciones europeas occidentales. Aquello que hace falta á la una lo posee en alto grado la población de la otra, y así es como únicamente la resultante de todas juntas produce la civilización completa que se desea trasladar.

De una inmigración exclusivamente inglesa, nadie podría exigir la excelencia del genio artístico francés, italiano ó español, y recíprocamente, estas nacionalidades por sí sólas muy difícilmente alcanzarían el alto espíritu de empresa y comercial, el genio mecánico y la tenacidad en la lucha con los elementos que caracterizan á la raza anglo-sajona.

Sin necesidad de entregarnos al análisis de las cualidades especiales á cada nacionalidad, nadie pondrá en duda la pluralidad y la diferencia de esas cualidades entre nación y nación, y la necesidad de aprovecharlas en donde quiera que se las encuentre.

Por otra parte, la variedad de nacionalidades en la inmigración produce en poco tiempo la fusión de las razas inmigrantes, condición de éxito primordial de toda empresa inmigratoria conscientemente dirigida; y así esa población extranjera en los comienzos, se transforma con rapidez en una población exclusivamente nacional, unida en sus ideales y esfuerzos por la felicidad de una patria común.

Más todavía: esa heterogeneidad de razas engendra el carácter democrático de la población; en tanto que siempre es difícil destruir, aún con muchos ańos de trabajo, los prejuicios y resabios políticos y á las veces autoritarios importados de las monarquías, cuando es una sola la raza que forma la corriente inmigratoria y tiene ocasión, por eso mismo, de conservarse exenta de alianzas extrańas de familia y de transmitir á dos ó tres generaciones las ideas y preocupaciones á que nos venimos refiriendo. 
El envío de emigrantes de nacionalidades diversas ha sido también la regla constante de esta Agencia. No ha sido posible, sin embargo, obtener la proporcionalidad deseada, debido á las constantes interrupciones y modificaciones del servicio. Sin embargo, hay opiniones respetables que sin contradecir nuestras conclusiones anteriores, se inclinan á excluir ciertas naciones europeas como fuentes de emigración hacia nuestro país.

Temerosos de provocar desagrados para algunas de las colonias extranjeras que viven hoy en nuestro suelo, no nos atrevemos á abrir discusión sobre este punto, pero á nuestro modo de ver, con tal que la elección de los emigrante: hecha escrupulosamente en todos los casos y en todos los países, creemos que la corriente inmigratoria debe partir, en lo posible, más ó menos por iguales partes de Francia, Alemania, España, Inglaterra, Suiza, Italia, Bélgica, Holanda, Austria. Suecia y Noruega.

Y en esto habrá que poner la atención más cuidadosa cuando los envíos sean hechos en grande escala, si no queremos padecer el desequilibrio que se ha producido á nuestra vista en otros países, como los Estados Unidos, por ejemplo.

Allí el predominio casi exclusivo de dos grandes nacionalidades que no podían importar el gusto artístico, produjo á la larga la carencia de este precioso elemento de la civilización; y solo al presente, en razón de los esfuerzos constantes de los particulares y de la guerra europea de 1870, que arrojo una abundante emigración artística sobre aquella nación, venimos asistiendo allí al nacimiento laborioso de las bellas artes. Pero á qué buscar el ejemplo lejos de nosotros mismos, si po- demos preguntarnos ¿cuál seria al presente el desenvolvimiento industrial y artístico de la América espańola, si en lugar de la exclusiva colonización hispánica, las nuevas poblaciones se hubieran formado con inmigrantes de las diversas nacionalidades europeas por iguales partes?

Y para terminar preguntaremos ¿es posible acaso poblar á Chile con los emigrantes de dos ó tres países europeos, cuando la diversidad de sus climas exigiendo la concurrencia de los habitantes del norte, del centro y del mediodía de este continente?

Después de lo dicho, nuestras conclusiones respecto de la primera cuestión que nos hemos propuesto, esto es, "existencia en Europa de población emigrante", no pueden ser dudosas: la abundancia de personas prontas á emigrar es enorme, y la conveniencia de Chile exige que ellas sean escogidas más ó menos por iguales partes entre las naciones europeas que hemos designado oportunamente.

(Segundo asunto) Condiciones del pais de inmigración.

Chile no está condenado á tener cuatro ó cinco millones de habitantes para siempre [...] muy pocos países nuevos reúnen mejores condiciones que el nuestro para ser habitados por una población floreciente, esencialmente manufacturera, de 35 á 40 millones de habitantes.

(Tercer asunto) Distancia entre los paises de emigración y el de inmigración.

He aquí la gran desventaja de nuestro país para procurarse inmigración. Si Chile, conservando sus actuales condiciones, estuviera situado á ocho ó diez días de viaje marítimo 
de la Europa, el exceso de habitantes lo habría colocado tiempo há en la situación actual de los Estados Unidos, que se ven obligados á rechazar la inmigración. La República Argentina tiene esa ventaja sobre nuestros treinta y tantos días de viaje.

\section{ANEXo 2. UN PROBLEMA NACIONAL ${ }^{23}$}

Subrayábamos que, por razones obvias, uno de los problemas más vivos y urgentes que dejará la posguerra será el de las grandes migraciones humanas, estimuladas por factores materiales, económicos y psicológicos.

Y acentuábamos, al anotar el hecho, la reflexión de que países jóvenes como el nuestro, de dilatado territorio y escasa población, debían prepararse para recibir a los elementos laboriosos que quisieran incorporarse a la vida nacional con el aporte del conocimiento y la experiencia en técnicas destinadas a promover nuestro adelanto y progreso.

Frente a quienes propugnan la acogida a una inmigración sin discriminaciones, sabemos que en ningún problema como en este debe pensarse en una rigurosa selección que tienda a incorporar a la nacionalidad elementos de orden y trabajo que impulsen con sus actividades la creación de nueva riqueza y que sean para el país que les abre las puertas de la convivencia, futuros ciudadanos o padres de hijos chilenos que sientan la dignidad de nuestra historia y el amor de nuestra tierra.
La grandeza y la prosperidad de países vecinos y amigos reconocen en buena parte, como una de sus causas y razones fundamentales, este aporte de la inmigración de grandes masas laboriosas que han tenido a honor fundirse con la nación hospitalaria que ha dado nuevas posibilidades a su vida y a la de sus hijos.

Si se ha repetido tantas veces, y con tanta verdad que "gobernar es poblar", ello no significa que la recepción de los nuevos habitantes del país se haga sin selección o discriminación previas. Se trata de recibir hombres de trabajo e iniciativas, a los cuales se desea ver arraigados en la tierra como troncos de nuevas generaciones de chilenos orgullosos y amantes de la tradición nacional.

Los países nórdicos, que tanta similitud tienen con el nuestro en sus condiciones de vida, podrían suministrarnos un material humano de primera calidad para intentarlo en nuestro pueblo y nuestra raza. Países mineros, pescadores, pueden venir en hora oportuna a prestar su impulso a la nación que busca en el trabajo su camino de superación y engrandecimiento.

Necesitamos, sobre todo, la contribución de los pueblos laboriosos, cuyos hijos, infiltrados en la vida del trabajo chileno, pueden traer nuevas modalidades que signifiquen, en lo material, mayor y mejor rendimiento $y$, en lo moral, un concepto claro y definido del cumplimiento del deber correlativo y previo al ejercicio del derecho.

23 Un problema nacional (1944, octubre 2). Editorial, El Mercurio, p. 3. 


\section{Anexo 3. Programa de inmigración ${ }^{24}$}

Chile necesita, y nadie puede dudarlo, recibir un fuerte aporte de sangre nueva, de elementos blancos, de razas fuertes, cultas y progresistas que hagan su nuevo hogar en nuestras tierras y que aquí edifiquen sus casas, formen sus familias y elaboren sus intereses. Las posibilidades que presenta nuestra patria para los elementos extranjeros son inmensas y los beneficios que a Chile pueden traer los continentes europeos son incalculables.

No puede desconocerse que Europa, gastada por conflictos interminables, florecida en una civilización y en una cultura milenarias, la más y avanzada que conoce la historia de la humanidad, padece de una sobre población que es el origen último de sus guerras intestinas, de sus rivalidades permanentes, de sus disensiones internacionales casi ininterrumpidas. En estas condiciones y atenidos al hecho expuesto cuya naturaleza no puede impugnarse, es lógico, más aún, es imperiosamente necesario que nuestro Gobierno aproveche estos factores para avecindar en Chile todo el elemento europeo, blanco que quiera emprender en nuestra patria la vibrante aventura de una nueva existencia.

Entre los países del norte de Europa, el Gobierno de Chile debe realizar gestiones para obtener la posibilidad de traer una in- migración, que por ser de aquellos países, ya de por si es seleccionada. Noruegos, suecos, finlandeses, daneses, holandeses pueden venir a poblar las tierras vírgenes de Chile, y traernos el regalo de una sangre activa y fuerte y de una cultura superior y poderosa, sin perjuicio de que lleguen a Chile contingentes de otras nacionalidades y de diversos territorios.

Para cumplir con los objetivos de la política que esbozamos, es necesario que exista un plan bien coordinado de inmigración, en que se den el máximo de facilidades a los extranjeros que vengan a trabajar al país en forma honesta, y que se eliminen las trabas odiosas y las exigencias inútiles.

Este plan deberá contar asimismo, con un estudio de las regiones del territorio nacional en que pueden ser afincados los contingentes inmigratorios que vengan a arraigarse al suelo chileno. Deben prepararse los sitios y regiones destinados a este objeto, y para este efecto, debe pensarse en las regiones inexploradas o poco conocidas de nuestra patria, como el territorio de Aisén, ponemos por ejemplo, en que existen posibilidades inconmensurables de dar acogida con expectativas de prosperidad a todos los inmigrantes que alcancen hasta Chile, y que vengan con el espíritu de echar, las raíces en nuestra nacionalidad, formando parte de ella.

24 Programa de inmigración (1945, octubre, 30). Editorial, El Mercurio, p. 3. 
ANEXO TABLAS

TABLA 1. POBLACIÓN E INMIGRANTES EN CHILE: 1854-2014

\begin{tabular}{|c|c|c|c|c|c|c|c|c|}
\hline $\begin{array}{c}\text { Años } \\
\text { censales } \\
\text { y estima- }\end{array}$ & $\begin{array}{c}\text { Población } \\
\text { de Chile }\end{array}$ & $\begin{array}{c}\text { Tasa de } \\
\text { crecimiento } \\
\text { medio anual }\end{array}$ & $\begin{array}{l}\text { Población } \\
\text { extranjera }\end{array}$ & $\begin{array}{l}\text { Propor- } \\
\text { ción ex- } \\
\text { tranjeros }\end{array}$ & $\begin{array}{c}\text { Tasa de } \\
\text { crecimiento } \\
\text { medio anual }\end{array}$ & $\begin{array}{l}\text { Europeos } \\
\text { sobre ex- } \\
\text { tranjeros }\end{array}$ & $\begin{array}{l}\text { Latinoameri- } \\
\text { canos sobre } \\
\text { extranjeros }\end{array}$ & $\begin{array}{l}\text { Otros } \\
\text { sobre ex- } \\
\text { tranjeros }\end{array}$ \\
\hline ción 2014 & $N$ & $\%$ & $N$ & $\%$ & $\%$ & $\%$ & $\%$ & $\%$ \\
\hline 1854 & 1.439 .120 & - & 19.569 & 1,36 & - & 34,8 & 56,7 & 8,5 \\
\hline 1865 & 1.819 .223 & 2,1 & 21.982 & 1,21 & 1,0 & 53,7 & 41,4 & 4,9 \\
\hline 1875 & 2.075 .971 & 1,3 & 25.199 & 1,21 & 1,4 & 62,3 & 33,0 & 4,7 \\
\hline 1885 & 2.057 .005 & $-0,1$ & 87.077 & 4,23 & 11,0 & 30,1 & 67,2 & 2,7 \\
\hline 1895 & 2.695 .652 & 2,7 & 79.056 & 2,93 & $-1,0$ & 55,4 & 41,8 & 2,8 \\
\hline 1907 & 3.231 .496 & 1,5 & 132.312 & 4,09 & 4,2 & 53,3 & 42,7 & 4,0 \\
\hline 1920 & 3.731 .593 & 1,1 & 114.114 & 3,06 & $-1,1$ & 59,9 & 31,2 & 8,9 \\
\hline 1930 & 4.287 .445 & 1,4 & 105.463 & 2,46 & $-0,8$ & 60,0 & 24,6 & 15,4 \\
\hline 1940 & 5.023 .539 & 1,6 & 107.273 & 2,14 & 0,2 & 67,2 & 21,7 & 11,1 \\
\hline 1952 & 5.932 .995 & 1,4 & 103.878 & 1,75 & $-0,3$ & 55,9 & 23,4 & 20,7 \\
\hline 1960 & 7.374 .115 & 2,7 & 104.853 & 1,42 & 0,1 & 60,9 & 26,1 & 13,0 \\
\hline 1970 & 8.884 .768 & 1,9 & 90.441 & 1,02 & $-1,5$ & 53,3 & 34,4 & 12,3 \\
\hline 1982 & 11.275 .440 & 2,0 & 84.345 & 0,75 & $-0,6$ & 31,8 & 54,5 & 13,7 \\
\hline 1992 & 13.348 .401 & 1,4 & 114.597 & 0,86 & 3,0 & 20,1 & 65,1 & 14,8 \\
\hline 2002 & 15.116 .435 & 1,2 & 184.464 & 1,22 & 5,8 & 17,2 & 71,8 & 11,0 \\
\hline 2014 & 17.819 .054 & 1,5 & 477.450 & 2,68 & 13,2 & 6,3 & 85,2 & 8,5 \\
\hline
\end{tabular}

Fuente: elaboración propia sobre la base de los Censos de Población 1854-2002. Para 2014 la fuente es el Departamento de Extranjería y Migración de Chile. Son estimaciones de extranjeros con residencia definitiva. La distribución por región de procedencia la ha realizado el autor sobre la base de extranjeros con residencia definitiva, 2013. Para la población de Chile 2014 se ha considerado la estimación oficial del Instituto Nacional de Estadísticas.

TABLA 2. POBLACIÓN DE AMÉRICA LATINA POR GRANDES GRUPOS ÉTNICOS, 1650-1825

\begin{tabular}{|l|c|c|c|}
\hline \multirow{3}{*}{ Población } & 1650 & 1825 & Diferencia \\
\cline { 2 - 4 } & $\begin{array}{c}11 \text { millones } \\
\text { A }\end{array}$ & $\begin{array}{c}23 \text { millones } \\
\text { B }\end{array}$ & $\begin{array}{c}+12 \text { millones } \\
\text { A-B }\end{array}$ \\
\cline { 2 - 4 } & $\%$ & $\%$ & $\%$ \\
\hline Blancos & 6,4 & 18,9 & $+12,5$ \\
\hline Negros & 7,3 & 18,2 & $+10,9$ \\
\hline Mestizos/Mulatos & 5,9 & 27,1 & $+21,2$ \\
\hline Indígenas & 80,4 & 35,8 & $-44,6$ \\
\hline
\end{tabular}

Fuente: elaboración propia a partir de Mattelart y Mattelart (1965) y Rosenblat (1945). 
TABLA 3. COMPARACIÓN DEL NÚMERO DE INMIGRANTES LLEGADOS DURANTE LAS MIGRACIONES EN EL SIGLO XIX: ALGUNOS PAÍSES DEL CONTINENTE AMERICANO

\begin{tabular}{|c|c|c|c|}
\hline \multirow{2}{*}{ País } & \multirow{2}{*}{ Años } & \multicolumn{2}{|c|}{ Inmigrantes } \\
\hline & & $\mathrm{N}$ & $\%$ \\
\hline Argentina & $(1857-1894)$ & 1.437 .000 & 6,41 \\
\hline Brasil & (1855-1889) & 776.215 & 3,46 \\
\hline Canadá & $(1825-1891)$ & 2.703 .330 & 12,05 \\
\hline Chile & $(1850-1894)$ & 34.000 & 0,15 \\
\hline Estados Unidos & $(1820-1894)$ & 17.482 .959 & 77,93 \\
\hline Total & & 22.433 .504 & 100,0 \\
\hline
\end{tabular}

Fuente: elaboración propia con base en Vega (1896).

TABLA 4. PRESENCIA EUROPEA EN CHILE, 1854-1940

\begin{tabular}{|l|c|c|c|c|c|c|}
\hline \multirow{2}{*}{ Inmigrantes } & \multicolumn{2}{|c|}{1854} & \multicolumn{2}{c|}{1907} & \multicolumn{2}{c|}{1940} \\
\cline { 2 - 7 } & \multicolumn{2}{|c|}{ A } & N & N & C & N \\
\cline { 2 - 7 } & 1.929 & 9,86 & 10.724 & 7,97 & 13.933 & 13,05 \\
\hline Alemanes & 915 & 4,66 & 18.755 & 13,95 & 23.323 & 21,75 \\
\hline Españoles & 7.215 & 36,87 & 9.800 & 7,28 & 3.644 & 3,40 \\
\hline Italianos & 406 & 2,10 & 13.023 & 9,68 & 10.619 & 9,90 \\
\hline Ingleses & 1.940 & 9,91 & 9.845 & 7,32 & 3.303 & 3,08 \\
\hline Subtotal & 12.405 & 63,4 & 62.147 & 46,2 & 54.822 & 51,1 \\
\hline Total inmigrantes & 19.569 & 100,0 & 134.542 & 100,0 & 107.243 & 100,0 \\
\hline
\end{tabular}

Fuente: elaboración propia con base en los Censos de Población respectivos.

\section{REFERENCIAS}

Agar, L. (2014). La población de origen árabe en Latinoamérica: reflexiones sobre cohesión social. En Caro, I. (ed.) Del diálogo a la alianza de civilizaciones. Santiago: RIL Editores.

Agar, L. (2012). Migraciones posmodernas en Chile: reflexiones sobre cohesión social y diversidad cultural. Revista Palabra (12). Cartagena: Universidad de Cartagena, Colombia.
Agar, L. (2011). Migrations internationales et diversité culturelle au Chili: Les défis de la postmodernité. [Thèse de Doctorat] Université Paris Descartes Sorbonne - Paris V. Inédit.

Agar, L. (2009). Inmigrantes y descendientes de árabes en Chile: adaptación social. En Los árabes en América Latina: historia de una emigración. Madrid: Siglo XxI.

Agar, L. y Rebolledo A. (1997). El Mundo Árabe y América Latina. En La inmigración árabe en Chile: 
los caminos de la integración. París: Ediciones unesco/Libertarias/Prodhufi.

Blancpain, J. P. (1987a). Francia y los franceses en Chile (1700-1980). Santiago: Pedagogías Chilenas.

Blancpain, J. P. (1987.b). Cultura francesa y francomanía en América Latina. El caso de Chile en el siglo XIX. Cuadernos de Historia (7). Santiago, Chile: Universidad de Chile.

Bucher, G. (2001). Emigrantes e Inmigrantes en Chile, 1810-1915. Nuevos Aportes y Notas Revisionistas. Valparaíso: Universidad de Playa Ancha Editorial.

CEPAL. (2006). Migración internacional, derechos humanos $y$ desarrollo. Santiago: Naciones Unidas.

Echanove, C. (1963). Sociología mexicana. México. D. F: Porrúa.

Encina, F. (1983). Historia de Chile. Santiago: Ercilla.

Ferenczi, I. y Willcox, W. (1929). International Migrations. New York, USA: National Bureau of Economic Research.

Fernández, E. (2006). La emigración francesa en Chile, 1875-1914: entre integración social y mantenimiento de la especificidad. Amérique Latine Histoire et Mémoire (12). Recuperado de http:// alhim.revues.org/document $1252 . \mathrm{html}$

Fuentes. M. (2014). Geografía génica de Chile. Distribución regional de los aportes genéticos americanos, europeos y africanos. Revista Médica de Chile, 142, 281-289.

Fuenzalida, A. (1906). La evolución social de Chile (1541-1816). Santiago: Imprenta Litografía I Encuadernación Barcelona.

González, M. (2004). Algunos alcances de los procesos migratorios en América Latina en el s. XIX y xx: una mirada desde el contexto de los estudios postcoloniales. Proyecto Patrimonio. Recuperado de http://www.letras.s5.com/mgs051204.htm
Jara, M. (2002). Chinos en Chile:política consular y debate parlamentario a comienzos del siglo XX. Valparaíso: Universidad de Playa Ancha.

García, F. (2009). Inmigrantes y élites en Chile en diálogo intercultural de jóvenes de la comunidad árabe y judía en Chile, 213-231. Santiago: Fundación Ideas.

Girault, R. (1979). Diplomatie européenne, 1871-1914: nations et imperialisms. Paris: A. Colin.

Hatton, T. y Williamson, J. G. (1998). The Age of Mass Migration. Causes and Economic Impact. New York: Oxford University Press.

Mattelard, A. y Mattelard, M. (1965). La problématique du peuplement Latino-Américain. Santiago: Université Catholique du Chili.

Maffesoli, M. (2005). El instante eterno. El retorno de lo trágico en las sociedades posmodernas. Buenos Aires: Paidós.

Maffesoli, M. (2004). El nomadismo: vagabundeos iniciáticos. México D.F.: Fondo de Cultura Económica.

Miquel, M. (1863). La inmigración en Chile (escrito en octubre 1856). Estudios económicos y administrativos sobre Chile desde 1856 hasta 1863, 7-13. Santiago: Imprenta de Ferrocarriles.

Norambuena, C. (1995). La inmigración en el pensamiento de la intelectualidad Chilena: 18101910. Contribuciones Cientificas y Tecnológicas, xxv (109). Santiago: Universidad de Santiago de Chile, Área Ciencias Sociales y Humanidades.

Pellegrino, A. (2000). Migrantes latinoamericanos: sintesis histórica y tendencias recientes. Santiago: CELADE - Naciones Unidas.

Pellegrino, A. (2003). La migración internacional en América Latina y el Caribe: tendencias y perfiles de los migrantes en BID/CELADE/CEPAL, Serie Población y Desarrollo, No 35. Santiago: Naciones Unidas.

Pérez Rosales, V. (1870). La Colonia de Llanquihue: su origen, estado actual y medios para impulsar su progreso. Santiago: Imprenta La Libertad.

OASIS, $\mathrm{N}^{\circ} 22 \cdot \mathrm{Julio-Diciembre} 2015 \cdot \mathrm{p}$. 49-91 
Pérez Rosales, V. (1857). Ensayo sobre Chile. Biblioteca Digital de la Universidad de Chile. Recuperado de http://mazinger.sisib.uchile.cl/repositorio/lb/ uchile/perezrosalesv01/

PNUd (2014). Informe sobre Desarrollo Humano 2014. Sostener el progreso humano: reducir vulnerabilidades y construir resiliencia. Nueva York: Programa de las Naciones Unidas para el Desarrollo.

Rosenblat, A. (1945). La población indigena de América Latina. Buenos Aires: Institución Cultural Española.

Sánchez, B. (2002). La época de las grandes migraciones: desde mediados del siglo xIX a 1930. En Colección Mediterráneo Económico, Proceso migratorio, Economía y Personas, 1. Madrid: Instituto de Estudios Socioeconómicos de Cajamar.

Subercaseaux, B. (2007). Nacionalismo y cultura: historia de las ideas y de la cultura en Chile. Santiago: Ciudad Universitaria.
Vega, N. (1896). La inmigración Europea en Chile, 18821895. París: Agencia General de Colonización del Gobierno de Chile.

Vergara, A. (1900). Población de Chile. Estudio sobre su composición i movimiento. Santiago: Editorial La Prensa.

Villalobos, S. (1992). Chile y su historia Santiago: Editorial Universitaria.

Villalobos, S., Silva, O., Silva, F., Estellé, P. (1976). Historia de Chile. Santiago: Editorial Universitaria.

Walbaum, V. (2004). Los Walbaum: una familia británica en Chile (1973-1945). Santiago: Instituto de Historia, Pontificia Universidad Católica de Chile.

Zavala, J. M. (2008). Los colonos y la escuela en la Araucanía: los inmigrantes europeos y el surgimiento de la educación privada laica y protestante en la región de la Araucanía (1887-1915). Universum, 23 (1), 268-286. Recuperado de http://www.scielo.cl/scielo.php?pid=S071823762008000100013\&script=sci_arttext. 